\title{
Afghanistan Series on \\ Tolerance, \\ Conflict Resolution \\ and Culture of Peace
}

Draft for Testing

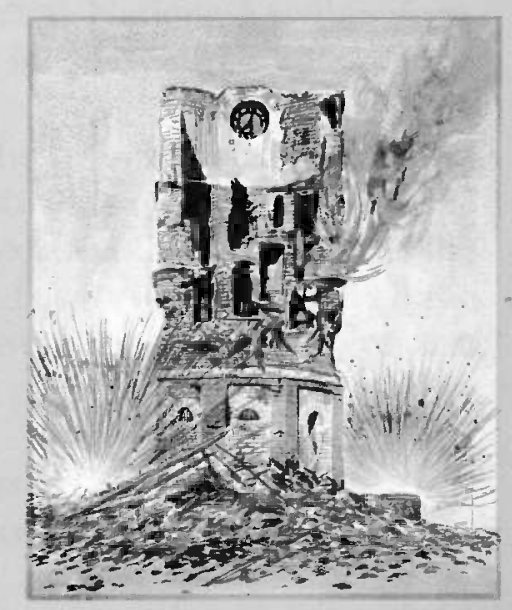

Theme-8: War and Destruction

- A Longing for Home

- Thinking of an Unseen Father

- In a Tent of Sarshahi Camp

- An Old Man Remembers

- To Hell with Money

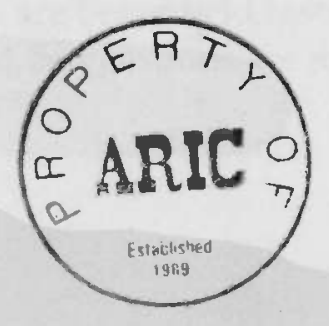




\section{Preface}

Peace, it is now universally recognized is a pre-requisite for the socio-economic development of individuals, societies and nations. The United Nations has therefore, been striving from its very inception to bring about peace in the world, and save the future generations from the ravages of war.

Among other measures there is a need, to combat the growing intolerance and hatred, and promote a culture of peace, amity and goodwill among people at the national and international levels. The United Nations has dcclared the year 2000 as the International Year for Culture of Peace, and UNESCO as the Focal Agency to launch the programme. The choice seems most apt, for UNESCO's constitution reflects its concern for peace in the following words:

"That since war begins in the minds of men, it is in the minds of men that the defences of peace must be constructed."

Education, is a key area which could be effectively employed to grapple with fanaticism, religious and racial prejudices, violence and intolerance which seem to threaten the very fabric of our civilization and world peace.

Of all other countries, Afghanistan has suffered one of the worst socio-economic upheavals in recent times, on account of war and internal turmoil, and is in urgent need of peace so that conditions may normalise, refugees return to their homes, and people settle down to their daily routines once again.

Recognising therefore what has befallen the country, and the catalytic role that education can play in fostering a better understanding among the people, UNESCO Islamabad supported a process of developing reading materials for Afghan youth, especially students. A 10-day workshop was organized in April, 1999 in collaboration with AG BAS-Ed and participation of UNHCR. Twenty five Afghan educators and writers attending the workshop assisted in preparing suitable material in the form of essays, puzzles, poems, etc.

Fifty of these were finally selected on the basis of their themes, and are being published in Dari and Pashtu in the form of eight booklets in the present series. An attempt has been made to use everyday language to avoid problems of comprehension. Also, a racy style has been maintained to hold the interest of potential readers. The English version is for the general reader.

The Dari and Pashtu versions are being field tested. These will be further refined on the basis of feedback from the field. Suggestions are most welcome.

June, 2000

P. K. Kasaju

Director/Representative UNESCO, Islamabad 
We express our gratitude to the following Afghan authors, for their contribution to this serial:

\section{- Zulmay Hewadmal}

\section{- Samiullah Taza}

The opinions expressed in this series represent the views of the authors, not of UNESCO. 


\section{A Longing for Home}

Bakhtawara and her brother Khyali were happy beyond measure, because preparations had been made for their return to their country.

Finally, the day came and leaving Torkham, they stepped on their motherland, for the first time. Their parents had taken refuge in Pakistan seventeen years ago, and they were born in the refugee camps on the outskirts of Peshawar.

Now, on their way to Jalalabad, they could see nothing but ruined villages and school buildings, the big camp of displaced persons in the midst of hot, dry desert and destroyed tanks, and vehicles littered all along the road.

At last, they arrived in Jalalabad and then went to their village. "Here, kids we have arrived at our village," said their mother, trying to cheer up her children. But then looking around she exclaimed, "O God! how much has this village changed. Bakhtawara's father where is that big garden? Oh God! Look at our houses. It seems as if somebody has rooted them out and thrown them away." Then after a pause, "Oh! where are the Spera mountains."

Going around the village, the family was astonished to find that most of the houses had been destroyed; only a few families, which had recently repatriated from Pakistan, had rebuilt their houses. The flood tract appeared to have grown wide and deep, farms had been washed away.

The family spent a few days in the village, and visited the deserted lands, as well as the bare mountain. "Since the last two years," explained one of the villagers, "terrible floods have roared down this bed, and run over the village and farms." members.

"Are the rains responsible for these floods?" asked one of the family

"No," replied the villager, "the floods have been caused by the felling of trees; the mountains are now bare. With the commencement of the civil war, the people were forced to flee and the forester could not look after the trees. Unscrupulous people, therefore, violating all laws and ignoring our national interests, mercilessly cut down all the trees. One day, I went to the upper valley and saw large piles of wood. Dozens of mules were being loaded to carry it off from there. The floods have caused deforestation. When the mountains were covered with trees, the rain - no matter how heavy - was absorbed by the roots of trees and bushes. So, the floods were not heavy or dangerous. Now, with nothing on the mountainside, the water flows fully in the form of terrible floods."

"Also," added another villager, "forests have a good impact on the weather. Where there are no forests, the weather is sometimes too cold and sometimes too hot." 
"Another important thing," pointed out a third villager, "is that forest animals such as leopards, wolves, foxes, monkeys etc., as well as creepers and birds, have their own significance in the preservation of enviromment. If the forests are felled, the animals, creepers and birds vanish and locusts and mice appear in our farms, and scorpions increase in number."

"It is not only the felling of trees," said a teacher among the gathering, "but some people have been taking out talc and marble and selling it out for almost twenty years now. They have made huge profits this way."

"Let alone talc," said the second villager, "a huge mine of coal was also discovered at Woch-kot. It has been dug at twelve different points, and hundreds of truck-loads have been carried away. Also, during war years, outlaws are reported to have dug out various types of minerals, and taken them out of the country."

The family now returned to their home, much perturbed and dejected, over what they had seen and heard.

\section{A Visit to Kabul}

From their village, the family decided to go to Kabul. Bakhtawara and Khyali, their parents thought had not seen Kabul, and a visit to their aunt who lived there, would provide them an opportunity to do so.

On their way to Woluswali, Jalalabad and Kabul they could see only ruins of schools, hospitals, bridges and public buildings: an aftermath of the war. At last they arrived in Kabul.

Bakhtawara and Khyali were dismayed with what they saw. They had been told so much about the beauty and charm of Kabul. Instead, the roads and streets they came across were in a state of utter disrepair and neglect, the buildings and factories in ruins. "My son," said Lalgul, "some twenty years ago all our highways from Torkham to Kabul, from Kabul to Kunduz and Sher Khan Bander, from Pul-e-Khumari to Mazar-i-Sharif, Shibirghan to Herat, from Herat to Torghundi and Islamqala, also from Kandahar to Speenbuldak, from Kabul to Gardez and Khost, from Surkhakan to the center of Laqhman, were asphalted. Also, the road from Jalalabad to Assadabad, capital of Kunar province, was asphalted up to Nurgul area. Hundreds of tanks and other chain driven vehicles have passed over these roads, or they have been mined or bombarded. Explosives too demolished hundreds of buildings, big and small. Virtually all roads have suffered such a fate throughout Afghanistan."

The children, who were visiting their homeland for the first time, were baffled by the damage done by the war. "There was a time," said their father, "when a bus left Kabul for Herat at six o'clock in the morning, and arrived at its destination at eight in the evening. Now a bus arrives at Herat on the fourth night after its departure from Kabul." 
The children pointed out now and again, that they could see nothing but ruins. "Well, a bloody war has been raging in the country since the last twenty years. War is nothing, but destruction. The Russian forces had attacked us, and a relentless war ensued. The Khalqi and Parchamis, together with the Russians, struck our people from the land and air. They bombarded towns, farms, gardens, Karazes, dams, canals, and bazaars. They hit and blew everything with cannon, tanks and rockets. When they entered the villages, they massacred the inhabitants and did not even spare dogs, chicken, cows and sheep. They burnt the forests with bombs."

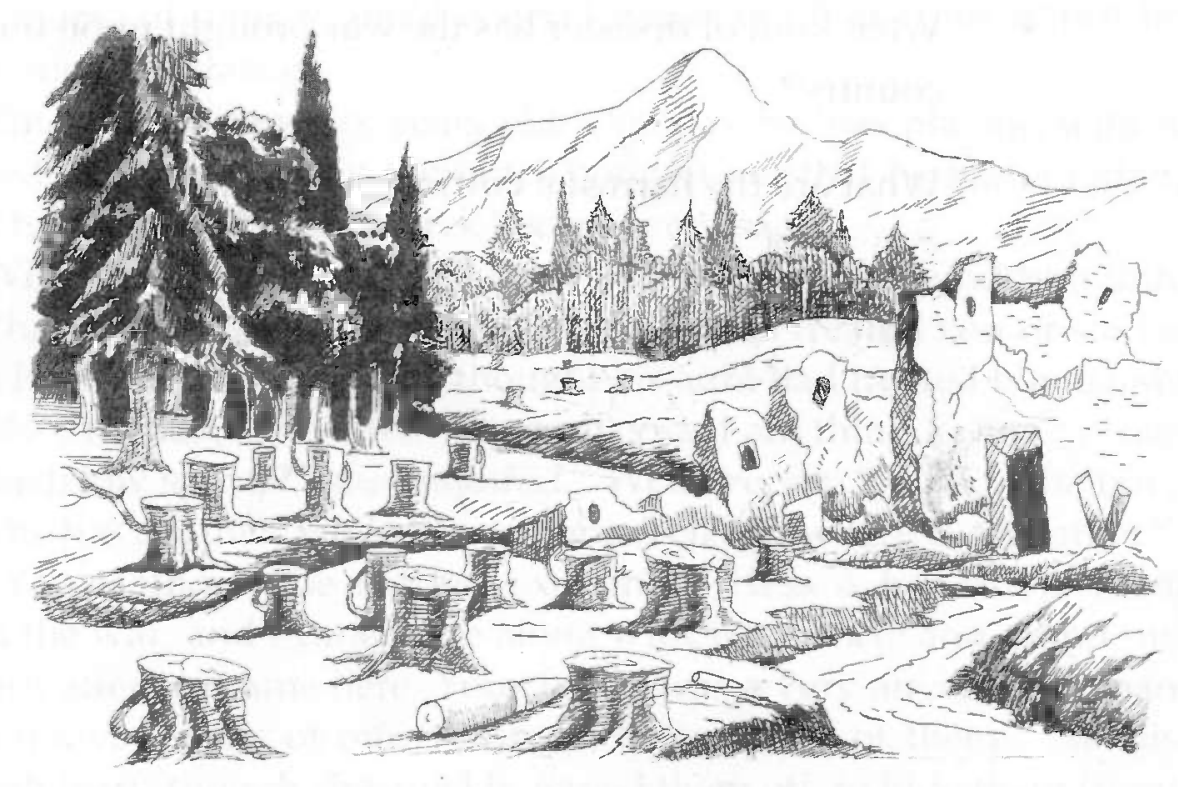

"These wars", he continued after a pause, "have changed our urban zones to deserts. The people left the villages and fled to the cities, or crossed the border. Some went to Iran, others to Pakistan, and a few overseas. When the Khalqis and Parchamis, along with the Russians, rushed upon villages and towns, the Mujahedeen counterattacked them with rockets and laid mines on the roads. They also set fire to large conveys, and shot down hundreds of jets, helicopters and aeroplanes." children.

"Well ! were not the Russians driven out long ago?" enquired the

"Yes," replied the father, "but armed Islamic parties then occupied various towns and cities including Kabul. The administration disappeared, life became unsafe and public, as well as private property, was looted. Power lines were cut and great damage done. Tens of factories were destroyed."

"That scems pointless killing and destruction," said the children.

"The war," continued the father, "swallowed our wealth. Many houses were shelled to dust in Kabul and other cities. With fresh waves of immigrations several more people left for Pakistan, Iran or Central Asian States. The camps 


\section{Thinking of an Unseen Father}

Zmarek's mother was a nurse, who worked in a Kabul hospital, his father a military officer, who was killed during the war. The mother had migrated to Pakistan after her husband's death, and presently lived in a camp at Thal. Her son was born there.

Zmarck's mother did not remarry and lived with her only son. When she started working at a hospital, her economic condition improved and she was able, in course of time, to build a small two-room house, for which her brother also provided assistance.

Zmarek was now six years old. One day he was playing with his cousin, who lived next door, when the latter pointed out that he had a father, whereas Zmarck had none. At this Zmarck become very sad.

When his mother returned from the hospital she found him unhapps and sad. "What is the matter, my son? Has any one ill treated you or said something that has hurt you?" Perhaps she thought his aunt had treated him harshly.

"No, replied," the boy, "no one has said anything to me." "Then why are you in such low spirits?" she enquired. "Well Prepay," replied the boy, "has told me that he has a father, while I have none. Tell me, where is my tather?"

"Your father," the mother explained, "was a handsome man. He was killed in the war, and 1 came here along with your uncle and grand mother. You were born after we came here. Your father was a very affectionate man. The war has taken away some of our best men, he was one of them". At this her eyes filled with tears, though she quickly wiped them off, to hide them from her son. with?"

After some reflection Zmarck asked again, "Who did my tather fight

"Your father," replied the mother, "was an officer in the Afghan army. A war has been going on for years between the Goremment and the Mujahedeen. The Russians came in support of the Government, which was being hard pressed by the Mujahedeen. The Government and the Russians dropped bombs and used heavy arms, which caused large scale casualties. The Mujhedeen in retaliation fired rockets. As a consequence there was a heary loss of human life."

"Was my father the only one to be killed in the war?" asked the boy" imnocently.

"Well the war has been going on for so many years, as 1 have already told you; over a million people have died."

"How much is a million?" asked the boy, failing to unclerstand the significance of the number.

"You know how much a thousand is. A million is a thousand thousand i.e. a thousand times a thousand." 
"Do you have a photograph of my father?" enquired the boy, "I want to see how he looked."

"Well I have it in my box. I'll show it to you."

A year later Zmarck joined his camp school. One day he saw two disabled refugees selling biscuits and chocolates in front of the school. He felt sympathy for them. One had lost both his feet, while the other had one hand and one foot. He mentioned this to his uncle Pero while coming home with him. "There are tens of thousands of such people in the country," said the uncle, "who have lost their hands and feet because of the mines laid all over the country."

The next day he went to the bazar with his grand mother. Someone called them refugees and said they should not come to the city. Zmarck asked his grandmother, "Why are we called refugees, grandma?"

"There is a terrible war going on in our country. Hundreds of thousands have been killed or maimed. We had to flee to save our lives. We left all we possessed behind, and have taken refuge here, so we are called refugees."

"Are we the only refugees?" enquired the boy.

"No," answered the grandmother, "almost half of the Afghans are presently refugees. Here in Thal Hargn, Bajawar, Dir, Haripur Mkenera, Mkyamwali, and in Baluchistan there are so many refugee camps. A good number of our country -men also live in Karachi, Lahore and Islamabad, while hundreds of others have taken refuge in Iran."

"Where are the refugees more in number? In Pakistan or lran?" asked Zmarck.

"I am not sure," replied the grandmother, "but your uncle listened to the radio which said that there are more refugees in Pakistan."

"I have also heard the radio say that a great many experts, scholars and educated persons have left for other countries."

"They had to leave the country," explained the mother, "because the Khalqis and Parchamis thought the learned people might not accept their ideology, and resist them. The others fearing a similar fate fled from the country."

One day Zmarck was seated by his mother, when a woman called and said that literacy courses had been started for men and women in the camp, and if there were any illiterates in their family, they may be sent to join these courses.

"Who are illiterates?" asked the boy.

"Illiterates," explained the mother, "are those who cannot read and write. The literacy rate was very low in our country, but now with schools destroyed or closed down in Afghanistan, and the boys forced to work for a living in other countries, the problem has become all the more acute. Therefore, literacy courses have been started in the camps, so that our boys and girls may learn to read and write." 


\section{Questions:}

- What do you learn from the story?

- What did Zmarck's parents do? 
"May the day come," said Lawang, "when the war stops and all of us including our brothers in foreign lands return to their homes."

"But," pointed out Nishter, "repatriation from Iran and Pakistan will pose problems. The Afghan refugees in these countries are engaged in some sort of work or the other. They mostly hail from the rural areas of Afghanistan. Land is no longer cultivable. Karezes and canals have been ruined, the irrigation system seriously disrupted, means of communication deranged, and the economy ruined. It is not easy for them to return home. Unless the irrigation system is put in order, repatriation seems impracticable."

"There is another aspect," commented another inmate, "there are millions of mines lying buried all over the country. We hear them explode every now and then, killing human beings and animals. Unless these mines are cleared, living and farming in the these areas seem almost impossible."

Another refugee who had recently returned to the camp from Peshawar now spoke: "Thousands of refugees are living in a miserable condition in other countries, many of them can be seen begging on the streets. This has sorely injured the self-respect and dignity of the Afghans."

"What is worse," said Lawang, "so many training camps have been set up in Afghanistan, which are training youth to fight in other countries. But perhaps the worst of all is the increase in cultivation of poppy and production of heroin, whose smuggling is bringing a bad name to the country and Afghans." All those present nodded in agreement and wished that peace was restored in Afghanistan at the earliest, then saying good bye to each other parted for their tents. 
"Kaka," asked Khan Gul, "was there any school in our area?"

"Yes there was a school by the flour mill in our village. Half the expenses of running it were borne by the community. The villagers had plans to build a girls' school as well, but the war overtook them, and they could not do so."

"It seems that people in those days were united," said Khan Gul.

"It was indeed so!" replied Kaka, "Conflicts and in-fighting were resolved by consultation, usually through Jirgas. It is only recently that people are being killed because they belong to another party, sect, tribe or group. There wasn't so much corruption either, nor was anyone killed because he did not say his prayers".

"Where will all this lead us in the end?" queried Khan Gul.

"All this is the result of ignorance," explained Kaka, "the Muslims are all brothers and so are Afghans. It is strictly forbidden in our religion to take the life of another human being. The imam had said at the Friday prayers, that according to our religion if a man kills another, it is as if he has killed all humanity. So you see it is a cardinal sin to kill a fellow human."

"But these people," said Khan Gul, "seem deaf and dumb. They do not pay heed to what God or His Prophet have said."

The call for prayer now having been made, both left to say their prayers.

\section{Questions:}

- Why did Kaka Nuruddin and his countrymen become refugees?

- Was there a school in Kaka Nuruddin's village?

- What was Kaka Nuruddin's attitude towards war? 
"She is right," said his uncle, "a few days back one of my friend's sons wanted to take him to the battlefield, saying that they pay a handsome amount to those willing to fight. I told him not to lure my boy. We did not need such money. If my son takes part in the war he will only kill his Afghan brethren, and I didn't want him to do that. Fighting the Russian infidels was a different matter. They had invaded our country. That was a holy war. But the present war is a sheer folly, a wanton killing of one's own countrymen. Therefore, the elders of our village decided unanimously after the Friday prayers in the mosque, not to allow any one to go to the war from this village".

"Well uncle, our villagers too have heard of your decision and are going to follow suit. Fazal Kaka's son is the sixth casualty from the war so far. All are unanimous except Commander Zafar. But the elders have warned that any one who insists joining the fighting will be forced to leave the village. The Commander was furious in the beginning, but then calmed down."

"The Commander can do nothing," said Mahboobullah, "One person cannot stand against the entire community. If none of us allows his son to go to the war it will stop of itself. After all we should ask ourselves what is that we are fighting for? We are human beings and should not indulge in this wanton carnage. Why should we kill our countrymen pointlessly?"

"I agree with you," said the nephew, "but I must not stay longer, mother should be expecting me by now."

\section{Questions:}

- Why had Kaka Fazal's son died? What had his father told him?

- Why had the mother of Hamid's neighbour wept?

- What had Mehboobullah's villagers decided upon?

- Why did not Kaka Muhboobulah allow his son to go to fight? 


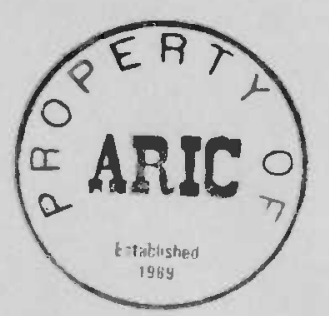

United Nations Educational, Scientific and Cultural Organization

First Floor, Saudi Pak Tower P.O.Box 2034, Islamabad, Pakistan Tel: (92-51) 829452 - 829453 - 813308 Fax: (92-51) 825341

E-mail: unesco@isb.compol.com 
Afghanistan Series on

Tolerance,

\section{Conflict Resolution \\ and Culture of Peace}

Draft for Testing

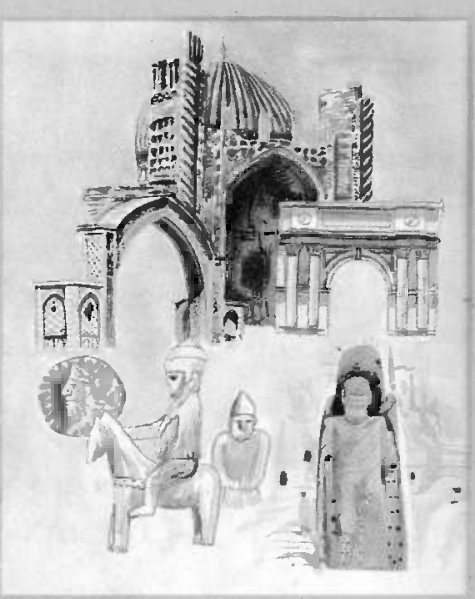

Theme-7: Culture and Historical Heritage

- Historical Monuments Belong to the Nation

- How Gulzar went to the Jergah

- Hasher: the Tradition of Building

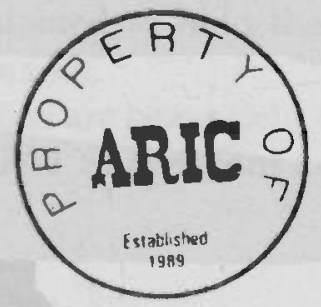




\section{Preface}

Peace, it is now universally recognized is a pre-requisite for the socio-economic development of individuals, societies and nations. The United Nations has therefore, been striving from its very inception to bring about peace in the world, and save the future generations from the ravages of war.

Among other measures there is a need, to combat the growing intolerance and hatred, and promote a culture of peace, amity and goodwill among people at the national and international levels. The United Nations has declared the year 2000 as the International Year for Culture of Peace, and UNESCO as the Focal Agency to launch the programme. The choice seems most apt, for UNESCO's constitution reflects its concern for peace in the following words:

"That since war begins in the minds of men, it is in the minds of men that the defences of peace must be constructed."

Education, is a key area which could be effectively employed to grapple with fanaticism, religious and racial prejudices, violence and intolerance which seem to threaten the very fabric of our civilization and world peace.

Of all other countries, Afghanistan has suffered one of the worst socio-economic upheavals in recent times, on account of war and internal turmoil, and is in urgent need of peace so that conditions may normalise, refugees return to their homes, and people settle down to their daily routines once again.

Recognising therefore what has befallen the country, and the catalytic role that education can play in fostering a better understanding among the people, UNESCO lslamabad supported a process of developing reading materials for Afghan youth, especially students. A 10-day workshop was organized in April, 1999 in collaboration with AG BAS-Ed and participation of UNHCR. Twenty five Afghan educators and writers attending the workshop assisted in preparing suitable material in the form of essays, puzzles, poems, etc.

Fifty of these were finally selected on the basis of their themes, and are being published in Dari and Pashtu in the form of eight booklets in the present series. An attempt has been made to use everyday language to avoid problems of comprehension. Also, a racy style has been maintained to hold the interest of potential readers. The English version is for the general reader.

The Dari and Pashtu versions are being field tested. These will be further refined on the basis of feedback from the field. Suggestions are most welcome.

June, 2000

P. K. Kasaju

Director/Representative UNESCO, Islamabad 


\section{Historical Monuments Belong to the Nation}

Sharifa is a bright young girl, studying in the eleventh grade at a school in Kabul. One day, she told her mother that there had been a conference on "Culture and Historical Heritage", in her school, in which teachers and guests had delivered speeches. "Well, what did you learn from their lectures?" asked her mother, showing interest.

"Twenty years of war and destruction, they said," replied Sharifa, "had caused irreparable damage to many of our historical buildings, some of which had been robbed or destroyed, adding that we should be proud of our cultural heritage and treasures, and do our best to safeguard them."

"Did they cite examples in this regard?"

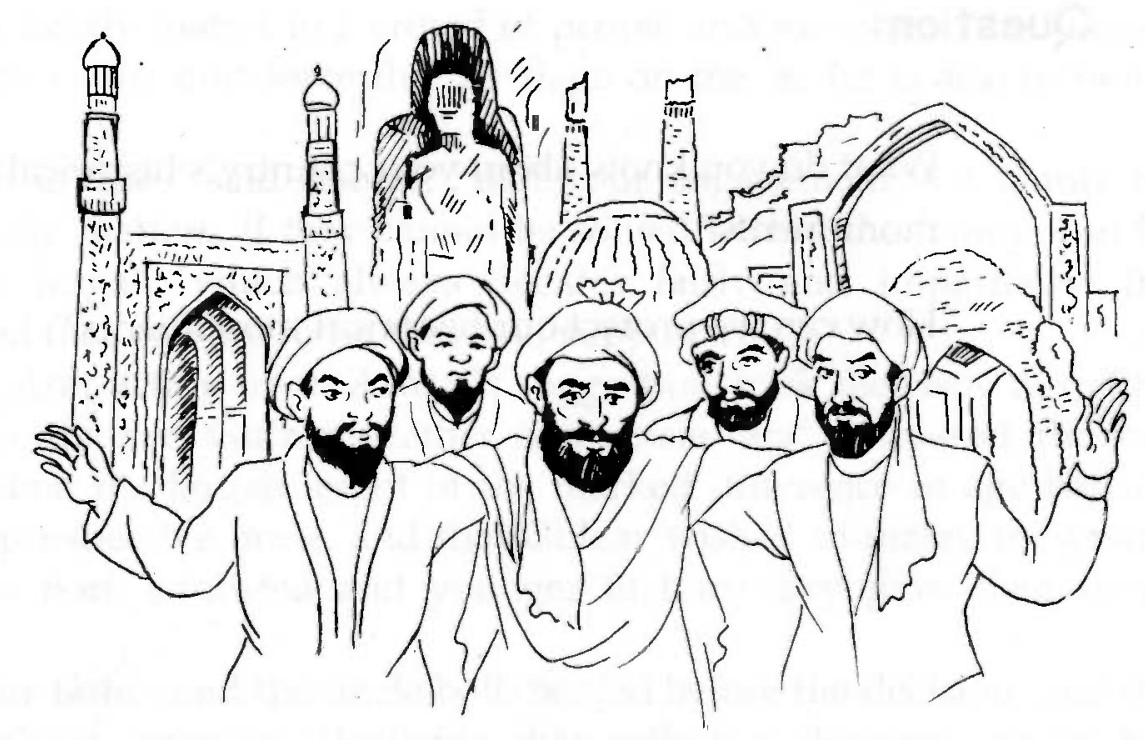

"Yes," replied Sharifa, "As our forefathers, they said, settled their disputes, successfully through the grand national Jergahs (councils), the present generations could do likewise, and settle them through mutual consultation and dialogue." say?"

"I agree," said her mother, "that it was a good practice. What else did they

"Some of the artifacts preserved in the Kabul Museum, they said dated back to 2500 years, while the statues of Buddha in Bamyan are the largest in the world. The minarets of Jam and Herat's Musalla, the great mosque of Herat Chehel Zina in Kandar, Aikhanum in Takhar, Hadda in Jalalabad, Takht-eRustum in Samangan, Qula-e-Bast in Helmand and Khawaja Mohammed Parsa's mosque in Balkh were some of the other historical monuments, they mentioned, 


\section{How Gulzar went to the Jergah}

Gulzar did not approve of many of his tribe's customs and traditions. As such they were of little interest to him. This caused an estrangement between him and the community, much to the concern of his father, who tried to argue and convince him to respect and abide by them, but to no avail. The matter took a turn for the worse for Gulzar, when his father decided upon his engagement with his cousin, who was not only older to him, but also illiterate. Gulzar left no stone unturned to convince his father to change his mind, but did not succeed in his purpose. He even asked his mother for help. The father however, remained firm.

Gulzar now did not know what to do. He consulted his friend Ashraf, who advised him to take the matter to the Jergah. Gulzar protested, "I do not like to take a family matter to a crowd of people and moreover, the elders may take my father's side, and force the marriage on me, as he is also a member of the Jergah."

"lt is true," said Ashraf, "that your engagement is a family matter, but such family matters, if they cannot be solved within the family, can be brought before a Jergah, which always decides fairly and impartially. If they are convinced that you are right, they will support you."

Gulzar acting upon Ashraf's suggestion, took the issue to the Jergah. The elders summoned Gulzar's father and uncle, and discussed the matter with them. When the Jergah learnt of the marked difference in age between Gulzar and his prospective bride, and that Gulzar wished to marry the younger sister, who was both educated and younger to him, they gave their verdict in his favour.

The father and the uncle both bowed before the decision, and the problem was resolved amicably. Realizing that collective decisions prove helpful and effective, Gulzar began to like and support the traditions of the Jergah.

\section{Question :}

- Should one follow the customs and traditions of one's tribe? 


\section{Hashar: the Tradition of Building}

Farooq, a high school student, told his father, "Father our teacher spoke about destruction and havoc, caused by war and conflict, and said that it would take a long time before we can reconstruct roads and buildings, including schools, hospitals and ancient monuments. So it will be a long time before such work begins, and that too after normal conditions have been restored:" "Yes", said his father, "we are faced with an uphill task. In fact, the war is still going on. But other countries have faced a similar situation and had to begin from scratch, to re-emerge as great powers. We have the example of Germany and Japan before us, though our case is not exactly like theirs".

"It is unfortunate," said Farooq, "that we have turned our country into ruins. When we travelled last year to participate in the wedding ceremony of my cousin, we saw no health centres, schools or any other building intact. All of them had been destroyed, as if they never existed. We likewise, did not see any historical monument, except those in a shambles. Under the circumstances, reconstruction shall have to begin from scratch. This seems an uphill task."

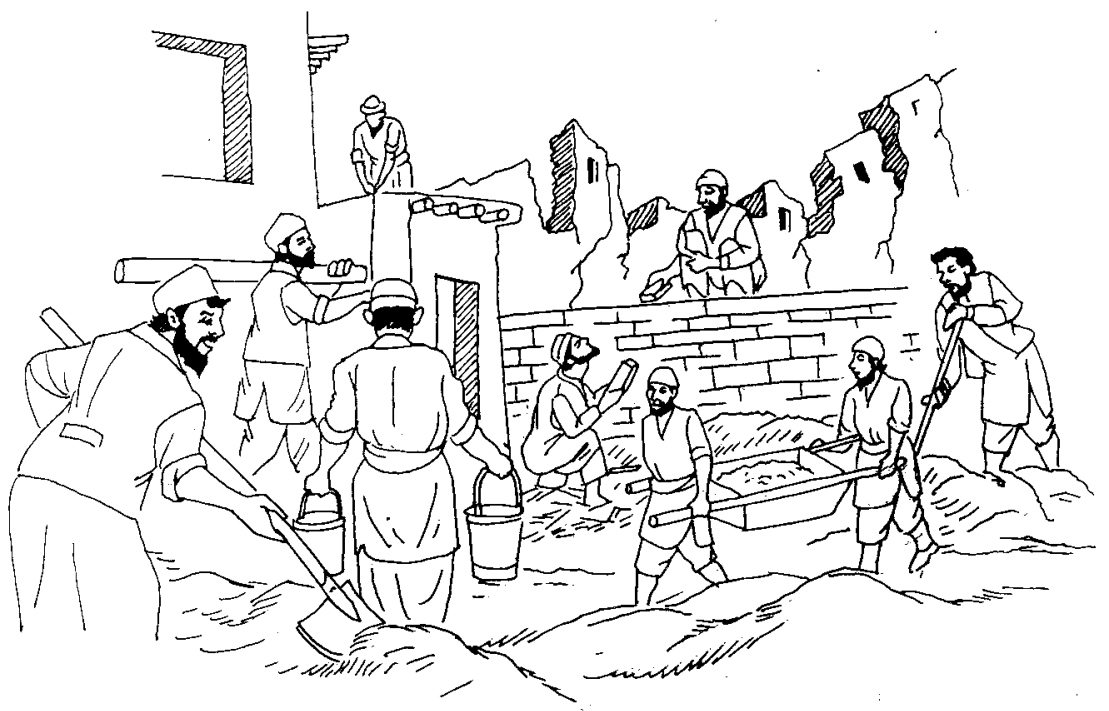

"As I have already said my son, we should not lose heart, but begin reconstructing as soon as possible, no matter from what. But I think we had better start with the rebuilding of schools and educational centres. If our children do not go to school, it will be a great national loss. We also need to rebuild clinics and hospitals, for it is said, that there can't be a healthy mind except in a healthy body. Our historical monuments come next. They tell us how our forefathers were able to create such marvellous works, and establish centres for scientific 
research and culture, through mutual cooperation, unity, and peaceful coexistence. We must also repair them."

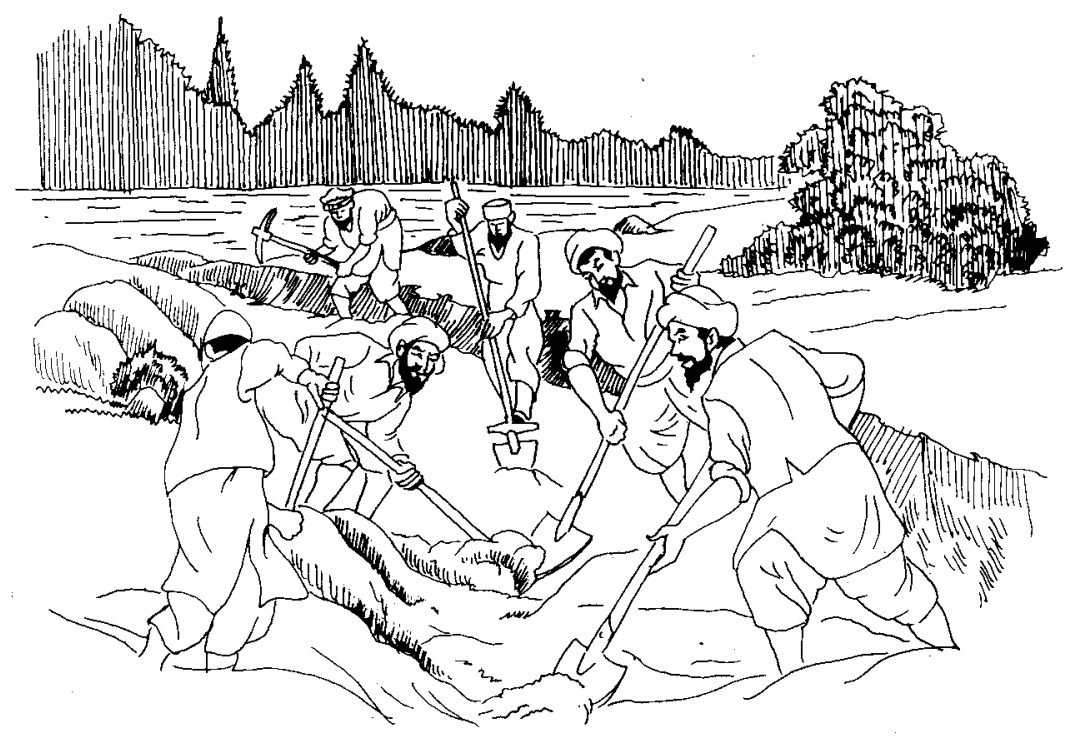

"We have a tradition of mutual co-operation called Hasher, through which, work is collectively done, to clear canals, construct roads, mosques, dams, and plough land and harvest the crops. We could, according to our tradition, seek assistance of the community, through Hasher. There is no point in waiting for outside help".

"I wish we could begin as soon as possible," Farooq said gloomily and left the room. 


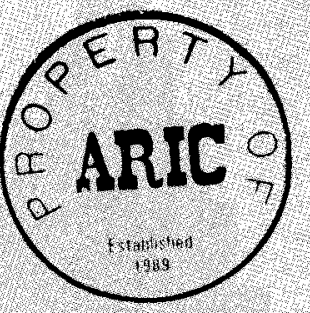

United Nations Educational, Scientific and Cultural Organization

Flrst Floor, Saudi Pak Tower P. O. Box 2034, Islamabad, Pakistan

Tel $(92-51) 829452-829453-813308$ Fax $(92-51) 825341$

E-mail unesco@isb.compol.com 
Afghanistan Series on

Tolerance,

Conflict Resolution

and Culture of Peace

Draft for Testing

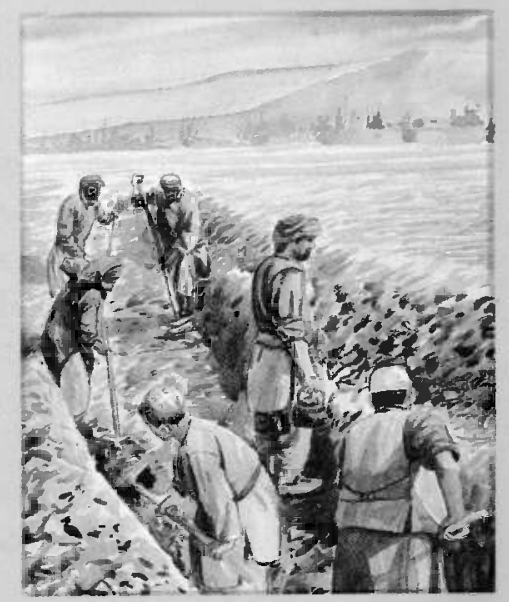

Theme-6: National Unity

- Mutual Respect: A Pillar of National Unity

- Marriage Unites

- Hopelessness is a Sin

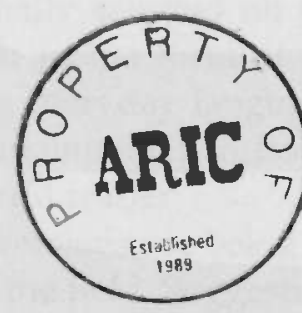

- Message

- Ahmad had to Apologize

- Discrimination is Forbidden

- Oh God Help!

- Let Our Ship not Sink

- Stories with a Moral 


\section{Preface}

Peace, it is now universally recognized is a pre-requisite for the socio-economic development of individuals, societies and nations. The United Nations has therefore, been striving from its very inception to bring about peace in the world, and save the future generations from the ravages of war.

Among other measures there is a need, to combat the growing intolerance and hatred, and promote a culture of peace, amity and goodwill among people at the national and international levels. The United Nations has declared the year 2000 as the International Year for Culture of Peace, and UNESCO as the Focal Agency to launch the programme. The choice seems most apt, for UNESCO's constitution reflects its concern for peace in the following words:

"That since war begins in the minds of men, it is in the minds of men that the defences of peace must be constructed."

Education, is a key area which could be effectively employed to grapple with fanaticism, religious and racial prejudices, violence and intolerance which seem to threaten the very fabric of our civilization and world peace.

Of all other countries, Afghanistan has suffered one of the worst socio-economic upheavals in recent times, on account of war and internal turmoil, and is in urgent need of peace so that conditions may normalise, refugees return to their homes, and people settle down to their daily routines once again.

Recognising therefore what has befallen the country, and the catalytic role that education can play in fostering a better understanding among the people, UNESCO Islamabad supported a process of developing reading materials for Afghan youth, especially students. A 10-day workshop was organized in April, 1999 in collaboration with AG BAS-Ed and participation of UNHCR. Twenty five Afghan educators and writers attending the workshop assisted in preparing suitable material in the form of essays, puzzles, poems, etc.

Fifty of these were finally selected on the basis of their themes, and are being published in Dari and Pashtu in the form of eight booklets in the present series. An attempt has been made to use everyday language to avoid problems of comprehension. Also, a racy style has been maintained to hold the interest of potential readers. The English version is for the general reader.

The Dari and Pashtu versions are being field tested. These will be further refined on the basis of feedback from the field. Suggestions are most welcome.

June, 2000

P. K. Kasaju

Director/Representative

UNESCO, lslamabad 
We express our gratitude to the following Afghan authors, for their contribution to this serial:

- Ms. Zarghona Kakar

- Ms. Taiba Sahila

- $\quad$ Syed Mohammad Ibrahim Bamyani

- Ms. Aysha Aziz

The opinions expressed in this series represent the views of the authors, not of UNESCO. 


\section{Mutual Respect: A Pillar of National Unity}

Afghanistan is a land of diverse tribes and nationalities. If we wish to achieve national unity and promote a spirit of confidence, we should:

1. Respect each other's language, dialects.

2. Revere the customs and traditions of other nationalities and tribes.

3. Promote goodwill and understanding through educational institutions and public centres.

4. Encourage intermarriages between peoples of diverse tribes and groups.

5. Join others in their festivities and occasions of mourning. 


\section{Marriage Unites}

When Faridun's sister got engaged to Akmurad, he was so upset that he did not join in the marriage ceremonies. He could not however, find fault with his sister's husband, except that he belonged to a different nationality, from Sheberghan. Faridun had formed a biased opinion about him, because he had known a classmate from Sheberghan, who was rich, and conceited. He therefore, concluded that all people from Sheberghan were selfish and proud, and had on that account opposed his sister's marriage to Aqmurad.

Aqmurad's family too, did not like the people of Badakhshan, but had to bow before their son's wish. Faridun's sister in due time gave birth to a son. When the child grew into a little boy, the two families found themselves very much in love with him. In fact, the child was observed to be fond of his father as well as his uncle. Soon his love for both of them brought them closer to each other, and they became intimate.

Presently, Aqmurad's grandson has reached manhood. Looking back in retrospect, Faridun's father recalls the strained relations between the two families and says, "It was indeed foolish of us to have thought that way. A marriage unites not only two people or families, but also two clans". 


\section{Hopelessness is a $\operatorname{Sin}$}

My uncle visited our house the other day, and I saw him talking solemnly with my father. "Should we hope that peace and tranquillity will prevail? The people are so disgusted with the events in this country, that it hardly seems so."

"We are Muslims," replied my grandfather, "giving up hope is a sin in our faith. Other nations have suffered a worse fate and recovered finally. Allah, the Almighty has said in the Holy Quran, that peace is the best recipe for mankind. Peace has therefore, been urged, because it is in such an environment that economic, social, and cultural development is possible."

"If that be so," said my father, "why doesn't the Almighty restore peace to Afghanistan? Our people have been going through psychological traumas for quite long now. He should have mercy on us."

"Peace," said my grandfather, "is not a miracle that one should expect from the heavens. It is we who have to strive

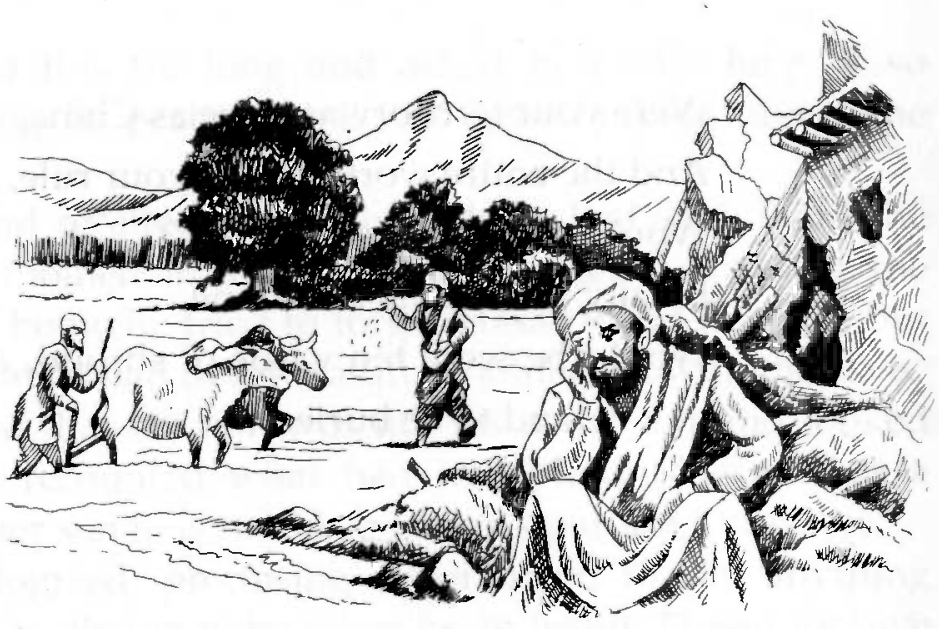
for it. Peace, we all know, can be achieved through negotiations, dialogue, and a desire to live in harmony. This is possible if the Afghans learn from their past mistakes and become tolerant of each other. Our nation is torn with political strife and we have suffered too long. God does not like bloodshed. It is time we all made efforts to bring peace to our unfortunate land."

\section{Questions:}

- Do you think, there will be peace in Afghanistan in the near future?

- How can we help in bringing about peace in the country? 


\section{Message}

O my friend, if your foe would not put up with you,

You should put up with him;

If not, wait for a while;

You will see neither him, nor yourself, nor Fakhr-e-Razi.

"Fakhr-e-Razi"

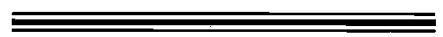

Were your territory as large as China,

And the entire world under your rule,

Would you be happy for this?

Finally your share and mine,

Would be were ten yards of shroud, and three yards of land to be buried in. 


\section{Ahmad had to Apologize}

I tasan and Ahmad were close friends. Ahmad lived in Kabul while Hasan had recently come from Chazni. They were classmates.

One dar their teacher was abeent and some of the students started talking about languages and dialects. The discussion soon became light-hearted. Almost creryone foined in the joking, and making pointed and cutting remarks.

In due time the bell rang, and the teacher of another subject walked in. The boy's took their seats and the discussion ended.

When Ahmad and Hasan left for home after school, Hasan would not communicate with him, and replied to his questions bricfly, mostly with a yes or a no.

Ahmad could not stand this for long and asked him why he was so detached. "On there is nothing in particular. I was just thinking about the discussion in the classroom."

Ahmad took the hint and recalled what the students had said about the Hazarayi dialect. He had also joined in and shared the jokes concerning the dialect. When Almad reached home he tried to forget Hasan's bad feelings, but could not. He was disturbed that he had upset Hasan by joining in with the class.

Ahmad's mother noticed that her son was not his usual solf and looked gloomy and pensive. Ahmad recounted what had transpired. The mother a kindly lady, at this instructed her son to go and beg Hasan s pardon.

Ahmad went and apologized, promising never agrain to say anything concerning languages or dialects, that may be taken as an insult. Hasan forgare him and they became friends again. 


\section{Discrimination is Forbidden}

The son of a friend of mine came back from Canada, to get married in Peshawar. I thought my friend would be happy at that, but I found him gloomy and sad. I asked him why he was so downcast, only to be told that he wanted his son to return to Canada as soon as possible.

"Why do you want that?" I enquired, rather puzzled.

"When I asked my son, whom he would like to marry, his reply was that he would marry a girl who spoke his own language. I did not at first take him seriously, but then I found, he met Afghans from other ethnic groups rather coolly. Also, he conversed only in his own language, although he is equally at home with other languages spoken in Afghanistan. When I asked him the reason for that, he did not answer me directly, but suggested that I had better break off relations with all my friends, whose language was different from ours. I explained, that having enjoyed the most cordial relations with them for so long, I could not now break off abruptly, on the frivolous grounds that they spoke a different language." 'Well, then break off relationship with them, so long as I am here,' he said. I asked him the reason for this sudden change in his outlook, and what had brought about this resentment. His reply rather came to me as a surprise: 'The Afghans living in a foreign country,' he said, 'are divided in several groups on the basis of language and race. These groups prefer not to communicate with each other'."

"I am sure," I told my friend, "that the enemies who want to divide the Afghans on the basis of their ethnicity have influenced your son. Perhaps my uncle, who is a wise old man may advice him in the matter."

My uncle agreed to invite the boy and his father to dinner. He discussed the issue with the boy, and referred to what God had said in the Holy Quran concerning the matter.

"O mankind! We created you from a single (pair) of a male and female, and made you into nations and tribes that you know each other. Verily! The most honoured of you in the sight of Allah is the most pious among you "(Al Hujurat, verse 13).

All Muslims therefore, he explained to the boy, are brothers to each other, more so the nations and tribes that have existed together for hundreds of years. Our Prophet Muhammad (PBUH), he added, had said "Don't live in hostility with each other, and don't envy or break relations, or turn your backs on each other, and O slaves of Allah, be brothers to each other, and it is forbidden that a Muslim abandons a Muslim brother for more than three days, and does not show affection to him or breaks relations with him".

"The Prophet Muhammad (PBUH)", he further informed the young man, had said, "The doors of paradise are closed until hostility is over and reconciliation has been brought about." 
After a seemingly elaborate, and what seemed an unending discussion, my friend's son was convinced, and promised that he would try to enlighten the Afghans living in Canada, to live like brethren in peace and amity. He was told never to forget that:

We are neither Afghans, nor, Turks, nor Tartars

But the offspring of the same branch in one garden.

It means: Discrimination in colour and smell is forbidden to us, for we have been raised from the same spring.

\section{Questions:}

- Do you agree with what the wise man advised the youth who had come from overseas?

- What does the poet mean by "we have been raised from the same spring"? 


\section{Oh God Help!}

It was a hot summer's day. Habiba, who had almost finished her work, went to adjust the curtains so that the heat ma! not penetrate into the room. Hen mind wandered into the past. She recalled the damage caused by the war, how ignorance and egoism of a few, had resulted in the subsequent discord and endless strife and misery for the Afghans. Families had been separated, near and dear ones lost, and the country reduced to a state of ruin. She remembered that she once possessed a house and a yard where she grew flowers and vegetables. She now yearned to return to her home. In her mind's eve she could feel the scent of flowers, watted along by a light breeze. She recalled ton, wistfully how she did not have to pay for the education of her children, whereas now her husband and soms earned barely enough to pay the house rent, and houschold bills.

Other memories, spread over the last twenty rears, crowded in her mind as well. She had once been detained and yuestioned for a crime, she had nerer committed. One of her sons had been forcibly enlisted and sent to fight, while the other had been blown to pieces by a rocket falling in the neighbourhood. Also, a nephew had perished over a mine. She could still hear the Russians bombarding her village, and the Mujahedeen killing a family, despite their heart rending shrieks and cries. She had not forgetten the circumstances either, which had forced her to leave the country for an unfamiliar land, nor the way her property had been looted. There was none in her entire tamily who had not been affected by the happenings in Afghanistan.

Habiba too recalled the following words, often recited by her father from the Holy Quran:

"O! faithful, be just and do whaterer pleases God. Animomity should not deviate you from the way of equity. Be just because it is closest to abstemiousness."

Habiba wondered if her countrymen would ever lend an ear to those words. While reciting these verses, her eyes often filled with tears and in a choked roice she would raised her hands in supplication to the Almighty and crying loudly beg, "Oh God have mercy on us, or will this go on for erer?" 


\section{Let Our Ship not Sink}

Afghanistan is a land of free men, a distinct culture - the "heart of Asia." But unfortunately it has been turned into a ruin, and the majority of its citizens rendered homeless. Its national heritage and its monuments have been damaged, destroyed or looted. Our courage, however is alive. We must learn from our painful past and jointly strive to rebuild the country.

Perhaps a beginning can be made by reposing confidence and trust in each other, avoiding conflicts and honouring each other's rights. We must find the root cause of all our problems, think over them coolly in the best national interest, and reach decisions through dialogue and consensus.

Let us not forget that none, except the Afghans, will reconstruct Afghanistan. Peace, however is a pre-requisite for reconstruction. Nevertheless, cooperation should be extended to philanthropic organizations, who are assisting us to rebuild the country.

Simultancously, awareness needs to be created among ethnic and linguistic groups, that our future lies in peace and reconstruction. Already, much damage has been done to the country. It is time every one realized that hashish, marijuana etc are eating into the vitals of the people, and cultivation of poppy must be discontinued. What the nation needs is concerted hard work, unity, selfreliance and social order. Much time has already been lost. Let us begin to reconstruct. 


\section{Stories with a Moral}

\section{Monkey's Mediation}

Once upon a time there were two wild cats. They lived on hunting birds. One day while passing by the wood, they found some cheese. They wanted to divide it equally between themselves, but had different opinions, as regards the quantity. They thought for a long time, but were unable to divide the cheese, in two equal parts.

One of the cats said, "Let us sit down and eat it, till it is finished." "No," said the other cat, "we cannot count thus. One of us might eat more than the other, that way. Let us look for someone, who knows how to divide things equally."

The other cat did not agree to this. "Suppose we find somebody to share it equally between us. But don't you think, he too will ask for a share, for doing that for us?" "No," said the second cat, "there are animals, who will not expect any share in our cheese. There lives an old monkey in our neighbourhood, who is said to be very wise and just. Let us go to him and ask for his help in the matter. Whatever happens, monkeys are more experienced. Perhaps, the just monkey will show us a way, to divide our cheese equally."

After much argument and discussion, the cats agreed to ask the monkey, for help. So they took the piece of cheese to him, and asked him to divide it in two equal parts.

"Dividing cheese is a very difficult task, and it has to be done with meticulous care, so that a square deal is ensured. Every craft has its instruments; the instrument for ensuring equitable division is skill. I have learnt how to do it. It was good that you came to me. I will make a scale for you now."

Saying this, the monkey. picked up two orange rinds, and with some thread and a small stick made a scale. Then with a hard blow from his fingers, he cut the cheese into two pieces, and put them in the scale. But one piece seemed to tilt the scale.

To make the pieces equal, he cut from the piece that was heavier, and ate it. Still, he could not balance the scale. The monkey continued cutting and eating piece after piece, from the heavier part, till the cats became suspicious and angry.

The monkey fearing that the cats might now attack him, thought of a pretence so that they may not do so. "What kind of a cheese is this? I have been distributing cheese to rats and cats for many years, but 1 have not seen one like this, which does not balance. Weighing it is a headache."

One of the cats replied irritably: "We don't know, we have not tasted it." 
"It is obrious," said the monkey, "had you tasted it, you would have understood what I am saying. You know that the distribution of this piece is not an easy task."

With this the monkey started balancing the scale again, and while holding it in one hand, kept on cutting and swallowing from the heavier side, till only a little piece was left in one of the pans. At that, the supposedly just and honest monkey said, "I am so tired .You wait a minute. Everything will be fine." Then eyeing the cats hypocritically, he put the last piece in his mouth and said, "This is my fee for balancing. You too, should adhere to justice, and not argue over trivial matters. I gave you a hand, and performed the hard task of distributing the cheese, otherwise some cruel individual would have deprived you of it all." When the cats' saw that no cheese was left, they started roaring at each other. One of them said angrily, "It was your fault, you told me to go to the monkey and ask him to distribute the cheese for us."

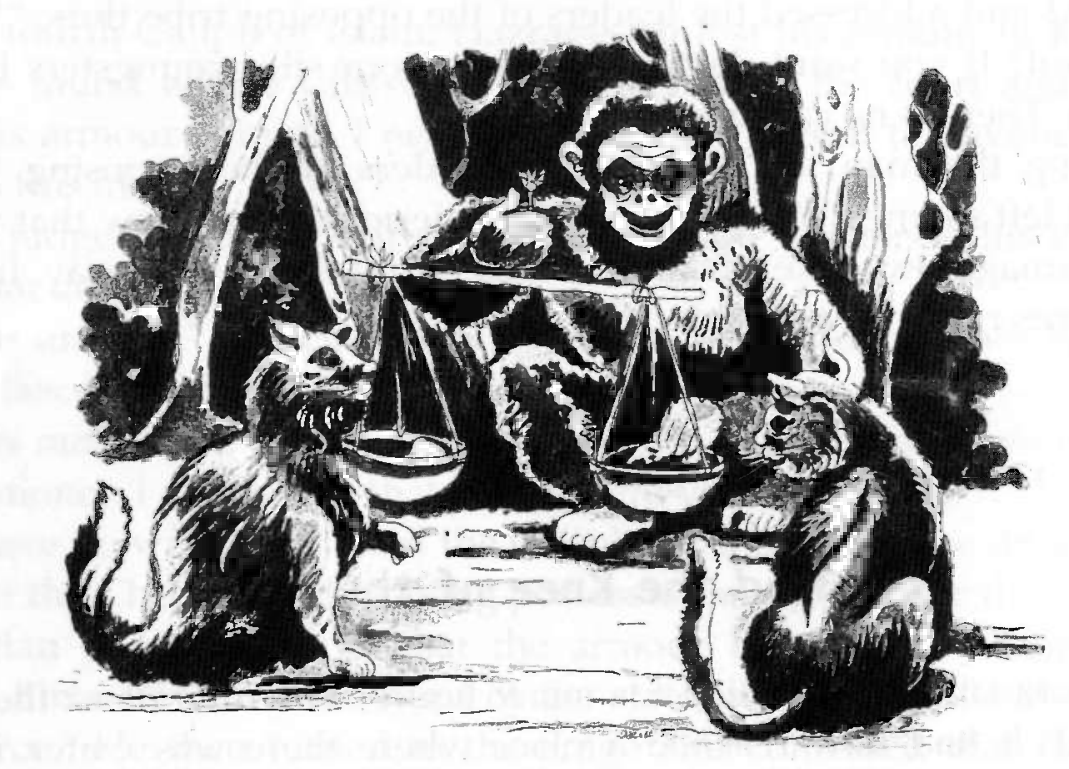

The other replied, "No, it was your fault, you wanted to eat more. Do you remember I once found a piece of bread and vou ate most of it." After violent arguments the cats started fighting. Noticing the pugnacious attitude of the cats, the monkey warned them, "Look, this is not a place for a quarrel! I think you had better go and live in amity, try to get better cheese next time and come to me, I shall portion out your shares equally between you."

"Now come let me reconcile you," he said as a last gesture.

"No, sir that is enough! We understand your tricks perfectly well now. We'll get along cordially, and not bother you again".

The moral: Do not quarrel.

In unity lies strength. 


\section{The Man Who Asked For Advice}

A man from the desert went to Medina and asked the Prophet (PBUH) to give him an all-purpose advice. "Never get angry," the Prophet suggested and said no more. The man left for his tribe and when he reached there, he was told that an unpleasant incident had taken place, in his absence. The voung men of the tribe had raided the property of another tribe, and the latter had decided on revenge. The situation had become tense. The two tribes soon arraved themselves against each other, and fighting seemed imminent. On hearing this the man taking hold of his sword, decided to join the other warriors of his tribe. Just at that moment he remembered, he had sought the guidance of the Holy Prophet, who had asked him to keep his anger in check.

He regretted that he had been so excited, armed and ready to kill or get killed. He decided to follow the adrice of the Prophet, in letter and spirit. He went forward and addressed the leaders of the opposing tribe thus: "What is all this fuss about? If you want damages for what our silly voungsters have done, I'll pay them. There is no cause for bloodshed."

Hearing the man talk sensibly, the elders of the opposing tribe were satisfied and left saying: "We are in no way inferior to you. Now that you accept to pay the damages, we take back our claims." And they went away. In this way, the conflict was resolved amicably.

\section{He Tied the Knee of the Camel}

The caravan had travelled for many hours. The riders and their animals seemed tired. It had now reached a place where there was water. The riders alighted from their animals to rest. The Holy Prophet Muhammad (PBUH) was among them. He too came down from his camel, so that it could take some rest. Everyone around was trying to reach the water for ablution, as they wanted to pray. The Prophet was also going towards the water. After going some distance, he silently turned back to his camel. His disciples thought that the Prophet did not like the place, and might instruct the caravan to proceed and halt at some other spot. But they were surprised when ther saw him tie the knee of his camel, and go in search of water. They cried, "O Messenger of God why did rou not tell us to tie the camel's knee?" The Prophet replied, "Never ask help for an thing that you can do yourself. Don't depend on others. He who helps himselt, God helps him." 


\section{An Advice}

A man once approached Prophet Muhammad (PBUH), and asked him to give him some advice. The Prophet said, "Will you follow the advice I give you?"

"Oh Yes, Prophet of God," replied the man earnestly. The Prophet again asked the same question and the man replied, he certainly would. In fact, the Prophet wanted to focus on the importance of the question.

"Well" said the Prophet, "when you decide on doing something, think carefully about its consequences. If it is likely to be harmful, don't do it."

\section{Caliph's Armour}

The fourth Caliph of Islam, Hazrat-e-Ali lost his armour in Kufa. A little later it was found with a Christian. He took him to the court and said to the judge, "This armour is mine. I neither sold it, nor gave it to anyone, and now I find it with this man."

The judge asked the Christian: "The Caliph has made his claim to this armour what do you have to say?"

"This armour," contended the Christian, "is mine. I do not however, say" the Caliph lies; he is probably mistaken."

"This man," said the judge addressing the Caliph,"denies your claim. You are the petitioner. I would like that you present your witnesses."

"I have no witnesses," said the Caliph. At that the judge decided the case in favour of the Christian, who taking possession of the armour decided to leave. The Christian however, knew that the armour belonged to Hazrat-e-Ali. He thought to himself, "Ali is the head of the state, and he could have proved his case by force." He then turned to the judge and confessed that the system of governance in Islam was the best, and converted to Islam. Later he fought at Nehravan under the banner of Islam. 


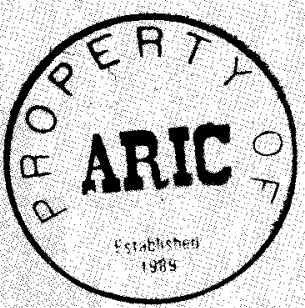

United Nations Educational, Scientific and Culturol Organization

First Floor, Saudi Pak Tower P O Box 2034, Islamabad, Pakistan

Tel: $(92-51) 829452-829453-813308 \mathrm{Fax}(92-51) 825341$

E-mail: unesco@isb.compol.com 
Afghanistan Series on

Tolerance,

Conflict Resolution

and Culture of Peace

Draft for Testing

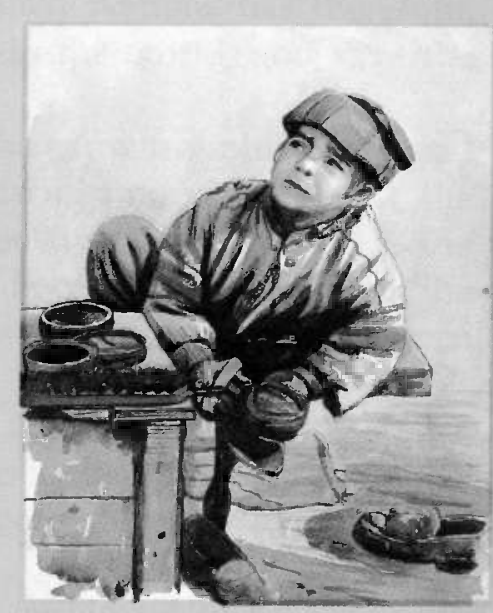

Theme-5: Human Rights and Social Justice

- Human Rights

- Caliph's Shirt

- Why?

- The Village Leader

- The Guiding Teacher

- My Younger Brother Cannot Read

- We'll Gain Victory

$\left(\begin{array}{ccc}0 \\ 0 \\ \text { ARIC }\end{array}\right.$ 


\section{Preface}

Peace, it is now universally recognized is a pre-requisite for the socio-economic development of individuals, societies and nations. The United Nations has therefore, been striving from its very inception to bring about peace in the world, and save the future generations from the ravages of war.

Among other measures there is a need, to combat the growing intolerance and hatred, and promote a culture of peace, amity and goodwill among people at the national and international levels. The United Nations has declared the year 2000 as the International Year for Culture of Peace, and UNESCO as the Focal Agency to launch the programme. The choice seems most apt, for UNESCO's constitution reflects its concern for peace in the following words:

"That since war begins in the minds of men, it is in the minds of men that the defences of peace must be constructed."

Education, is a key area which could be effectively employed to grapple with fanaticism, religious and racial prejudices, violence and intolerance which seem to threaten the very fabric of our civilization and world peace.

Of all other countries, Afghanistan has suffered one of the worst socio-economic upheavals in recent times, on account of war and internal turmoil, and is in urgent need of peace so that conditions may normalise, refugees return to their homes, and people settle down to their daily routines once again.

Recognising therefore what has befallen the country, and the catalytic role that education can play in fostering a better understanding among the people, UNESCO Islamabad supported a process of developing reading materials for Afghan youth, especially students. A 10-day workshop was organized in April, 1999 in collaboration with AG BAS-Ed and participation of UNHCR. Twenty five Afghan educators and writers attending the workshop assisted in preparing suitable material in the form of essays, puzzles, poems, etc.

Fifty of these were finally selected on the basis of their themes, and are being published in Dari and Pashtu in the form of eight booklets in the present series. An attempt has been made to use everyday language to avoid problems of comprehension. Also, a racy style has been maintained to hold the interest of potential readers. The English version is for the general reader.

The Dari and Pashtu versions are being field tested. These will be further refined on the basis of feedback from the field. Suggestions are most welcome.

June, 2000

P. K. Kasaju

Director/Representative UNESCO, Islamabad 
We express our gratitude to the following Afghan authors, for their contribution to this serial:

- Mr. Ghulamullah Weqar

- Ms. Aysha Aziz

- Ms. Najia Afshari

- Ghulam Dastgir Amanzai

The opinions expressed in this series represent the views of the authors, not of UNESCO 


\section{Human Rights}

Zirak Khan, a college going boy has an inquisitive mind. He likes to ask his father questions, to improve his general knowledge.

"What are human rights?" he asked him one day, "One hears these words so often on the radio."

"Man", replied his father, "is a social being. As such, he enjoys certain individual and social rights, which enable him to live amicably with his fellow beings in society. These are called human rights."

"What are these rights?" enquired Zirak.

These, the father said, were:

1. The right to live.

2. The right to freedom of expression.

3. The right to education.

4. The right to work.

5. The right to political freedom.

6. The right to own private property.

"The right to live! Could you please explain this in some detail?" demanded Zirak. "In the past", said his father, "the rich and powerful put the weak and poor to forced labour. In case of refusal they, at times killed them even if they were children. The Holy Quran mentions the cruelty of the Pharaoh, who killed the male children of the Israelites, and forced their girls to work for him. Likewise, in pre-Islamic times the Arabs buried their daughters alive. Also, people were mercilessly killed in war, and captives treated most inhumanely and tortured in various ways. From the Islamic viewpoint, and what is now generally recognized, all such actions are condemnable. In the battle of Badar, on the contrary, the captives were treated so well, that a good number of them converted to Islam."

"Please throw some light on the right to freedom of expression, as well," requested Zirak.

"It is said that there are four important freedoms: those of speech and religion, and freedom from fear and freedom from want. Freedom of expression means, that a man may be able to say and write what he wants, i.e exchange views freely, and disseminate information to his fellow beings as he may like. No restrictions should be imposed on him in this regard. Likewise, he may pray in the manner he may like. This is his natural right, and no one should interfere or dictate to him in matters of worship or belief."

"And how does one have the right to education?" enquired Zirak.

"Education is the birth right of all individuals. Before the advent of Islam, the right to acquire education was restricted to the privileged few. Islam put an 
end to this discrimination, and made it incumbent upon all Muslims to acquire knowledge," explained his father.

"And what about political freedom and the right to work?" enquired Zirak.

Political freedom denotes the right to form political parties, associate with people of similar views, and work for the welfare and betterment of the community and the people. By virtue of this right one can hold meetings, propagate one's political views, and conduct campaigns and contest elections."

"And what about the right to work," asked Zirak. "That means one may choose a profession," said his father, "in accordance with one's liking. No person can be forced to perform a job which he may not like, for one reason or the other".

"You have made all these concepts clear to me. What about the right to possess property?"

"There is a proverb," said the father, "which says that meat is for the eagles to eat. In the past, land, houses, property, and factories belonged to a few. The others only worked for them and got their wages. Some people therefore, were of the view that lands, factories and all other means of production, and indeed the whole economy, belongs to the state, and people, ought to work and get their wages. Islam holds that production should neither be owned, nor run entirely by the state, or a few individuals; it gives every one the right to earn through lawful means. A man if he earns through legal means, may even live opulently. A Muslim can also inherit property and wealth."

"I am grateful to you father for enlightening me on points which were not clear before," said Zirak.

"I would like to add," said his father "that there are a few other things, you must bear in mind. The Holy Prophet (PBUH) has directed his followers to greet each other on meeting, to visit and enquire about the sick, counsel each other to do good and treat the old, the young, one's neighbours, and one's friends with respect, love and affection. In particular, the faithful have been directed to look after their aged parents. We are also expected to attend funcral ceremonies, whenever it is so required. So you see Muslims have more rights, as well as obligations, towards their brethren-in-faith than people in other religions.

\section{Questions:}

- What are Human Rights?

- Do Muslims enjoy the right to freedom of expression? 


\section{Caliph's Shirt}

One day Umar Bin Abdul Aziz, the Caliph of Islam was preaching on the pulpit, when the audience realized that he stirred his shirt too often.

Wondering why he did so, some of the people, when his speech ended made enquiry, and found that the caliph had only one shirt, which he had washed and put on while it was still wet, and was now stirring it to dry.

This was the very core of the Islamic value of justice and equity, with the Caliph setting an example, in the golden age of Islam. No wonder, the rights of the individual were fully protected, and he felt secure.

\section{Question:}

- The rights of individuals are fully protected in Islam. Do you agree? 


\section{Why?}

Idrees is a young boy, and like other boys, wants to live in his own country, and speak his own language. Living however, as he is, in another land, he hates to be called a refugee. But he is forced to stay away because of the protracted war going on at home. Had it not been for religious, ethnic and linguistic prejudices, war would not have broken out in his country, and he would be among his countrymen.

Being a pensive boy several questions, continue to agitate his mind, to which he would like to have answers. For instance, why has he not been able to visit his country so far? Why do Muslims recite verses of the Holy Quran, but fail to follow its precepts in real life? Why are the Afghans so indifferent to their country's future, and continue to wage a senseless war? Why do they not divert their attention to the more pressing problems their countrymen are faced with, namely, poverty, ill-health, want and insecurity? Why are the Afghans being deprived of their right to education or a decent living? Why has the country's cultural heritage and industrial infrastructure been destroyed so heartlessly, and the social fabric of society rent apart? Why don't saner counsels prevail to put an end to this religious and racial fanaticism, as well as senseless vandalism, which have pushed her back into the Dark Ages?

Idrees, alongwith many others of his age, is living in a country, where except for those receiving financial help from relatives overseas, life is by no means a bed of roses: there is little money, job opportunities are few, and the family can barely manage to eke out a living. Envying his neighbours, who live in style and luxury, Idrees has become a staunch supporter of social justice, peace and religious tolerance. He dreams of the day when long lost peace will again prevail in Afghanistan, a democratic national government would be set up, and Afghans asked to return and live as brethren.

Perhaps, the following lines aptly express, what Idrees all along has had in mind:

"O Glorious Creature! O God! for how long shall I go from one place to another? Either close the door of my hopes or open the lock of my difficulties".

God says in the Holy Quran:

"We sent afore our messengers with clear signs and sent down with them the Book and the balance (of right and wrong) that may stand forth in justice (Al Hadid, 25). 


\section{Questions:}

- What is meant by 'being a refugee'?

- What are the pressing problems being faced by the people of Afghanistan at the moment? 


\section{The Village Leader}

Mosques are holy places where Muslims pray five times a day. Collective worship leads to fraternal love and closer ties, among those living in a locality. This ultimately leads to greater cooperation, and a better understanding in a community.

A scholar and an imam left for Kabul on a piece of business, and on return, talked with much concern and grief about the devastation they had scen there.

"We must focus attention on character building," said the scholar, "but for that we need to educate the people. The mosque, the family and the school, all must play their due roles, for bringing about a positive change in the outlook of the people. Elements that help in the building of character are 'tolerance and patience'. The mosque being the focal point of a Muslim's life, imams should play a pivotal role in bringing about this change. The imams should apprise the people what Islam enjoins on them. First and foremost, we must respect other people's views and beliefs. Everyone has a right to whatever he thinks or believes. We ought not to use violence in this regard. What have you to say, imam sahib?"

"Some people," the imam explained, "are in the habit of not listening to others, and jump to hasty conclusions. They interrupt when others are speaking, contradict them, and try to force their own viewpoint. This results in friction and tension. Imams should tell people that we must respect each other's views, and in no case create a misunderstanding by behaving discourteously towards others."

A village elder who was also present on this occasion now spoke:

"We should not believe in hearsay. It is important that we should verify carefully what is said and propagated, rather than jump to conclusions. Secondly, we should be careful about our language while discussing everyday matters. Remarks such as 'Mind your own business', 'you seem to think very highly of yourself', 'don't be a busybody', 'you are utterly ill-informed', only provoke anger and ill-will."

"I agree!" said the scholar, "We should show greater patience. Human beings are by nature sensitive to sarcasm, and lose patience when others make cutting remarks. Such behaviour only leads to hatred and animosity. Imams could focus on this point, and explain how this leads to bickering and serious quarrels."

"Children", said the village leader, "often provoke quarrels. If a child hits another, no matter, however slightly and in play, the latter goes and complains to his parents. Enraged and without thinking over the matter coolly, they pick up a quarrel with the other child's parents, resulting at times in serious fights. I remember once a boy had hit a neighbour's dog with a stone, because he thought 
it had been barking too often. The entire household reacted by coming out to belabour the boy. Fortunately, the neighbours intervened and an ugly scene was averted. The imams could therefore, guide the people and inform them that it is silly to quarrel over trifles."

"I agree," said the scholar, "but we should be wary of our utterances as well. We should not use abusive or derogatory language or call other people names, with the intention of humiliating them. There was once a man in our village who was small and dwarfish. People enjoyed poking fun at him by calling him 'shorty'. He resented this very much, and often retaliated by using grossly abusive language against his tormentors. Such confrontations at times took a nasty turn. The imams could provide a lead by advising the people in this regard as well."

\section{Questions:}

- Why should we take care not to contradict people?

- How are human beings sensitive to sarcasm? 


\section{The Guiding Teacher}

Rahim Khan like most other teachers, is patriotic and God fearing. He had gone to his friend Hanif Khan's house one day, when he saw his neighbour mercilessly beating his son. The shrieks of the boy attracted the neighbours, who intervened to put an end to the beating. Hanif Khan was enraged at this brutal treatment of the boy, but was restrained by Rahim Khan from picking up a quarrel with his neighbour, who after all was the boy's father, and responsible for his upbringing.

Later, Rahim Khan had much to say on the subject of upbringing of youth: they being the flowers and future hope of a country, the parents must deal with them gently and tactfully. Also, they need to be provided the right sort of environment, so that they can realize their full potential, and so on.

Rahim Khan considered the following points essential to ensure their moral and spiritual development on sound lines:

1. Children need love and affection. If they make mistakes, they should be corrected gently and tactfully, taking care that the objective is to reform rather than humiliate them.

2. Parents should be models of good behaviour and cooperation for their children, and avoid quarrelling in their presence.

3. Children, right from early years should be taught to respect their elders. This helps to develop a disciplined outlook in them.

4. Consultation with children, regarding selection of clothes and furniture, decoration of the house, their education and pastimes and affairs concerning the family, boosts their self-esteem and sense of participation in family affairs.

5. Parents should take interest in the education, pastimes and other matters concerning their children. In particular, they should be good listeners when dealing with them. Children like nothing better than the interest and attention, their family members evince, in their affairs. 
6. A friendly atmosphere prevents conflicts. If the environment at school, office, family and the mosque is friendly, students like to go to schools, workers to their offices, worshippers to the mosques and the family members enjoy being with one another.

\section{Questions:}

- Enumerate the points, which are essential for the moral and spiritual development of children.

- Should children be consulted regarding their education? 
you to continue your studies on coming here, but education is very expensive in this country."

"A nation can hardly be expected to progress without education," said Mustafa, "besides we need educated manpower to build our country."

"That would be possible," said the mother, "when the Afghans become prudent, stop fighting, and begin reconstructing."

At night Mustafa dreamt he was in the classroom where the teacher was discussing mines, untapped resources, the need to reopen educational institutions, and restore peace, so that the country could be put back on its rails.

Mustafa wanted to ask his teacher a question, but woke up. "Are there any mines in Afghanistan?" he asked his mother. "Yes", she answered, "of zinc, coal, copper, iron-ore, gold, silver, precious stones and many more. We also have lapis lazuli, turquoise, emerald, ruby, Shah Maqsud and decorative marble quarries, but they lie untouched so far."

"But why have these not been made operational so far?" asked Mustafa.

"These could not be tapped because of war and our scientific and technological backwardness. We would not be economically backward if our resources were suitably exploited," replied the mother.

"One can only hope peace will prevail, so that natural resources can be fully tapped, bringing prosperity to the country," said Mustafa resignedly.

\section{Questions:}

- Is female education important for a country in the modern times?

- Why has Afghanistan not been able to exploit its natural resources so far? 


\section{We'll Gain Victory}

We'll gain victory!

We'll gain victory!

We'll gain victory one day.

I believe so from the bottom of my heart,

That one day, we'll gain victory.

We'll walk hand in hand,

We'll live together in peace,

We'll all be free,

We are not afraid,

We are not alone,

Truth shall triumph and bring us victory.

\section{Questions :}

- What is this poem about?

- What is its key message? 


\section{Express What you Feel}

Students sit in a circle, forming a group. The group leader reads the following sentences, in the given sequence. Then each participant decides silently, whether he agrees with the sentence read out by the group leader, or not. Those who agree stand up, while those who do not, remain seated. Afterwards, the groups, one standing, the other sitting face each other, and explain why they agree or disagree.

This activity continues till all the sentences have been discussed:

1. Violence in families is the major obstacle to children's progress.

2. Boys should eat more than the girls, because they need greater energy.

3. The main objective of educating girls is to improve their socio-economic life.

4. Men play a more vital role than women, in the maintenance of peace.

5. Children should study half the day and play during the other half.

6. Children should decide whether to study in the morning, or in the afternoon. 


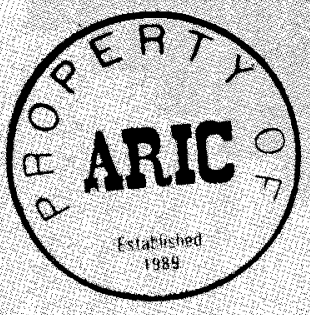

United Nations Educational, Scientific and Cultural Organization

First Floor, Saudi Pak Tower P O Box 2034, Islamabad, Pakistan

Tel. $(92-51) 829452$ - $829453-813308$ Fax. $(92-51) 825341$

E-mail. unesco@isb.compol.com 


\section{Afghanistan Series on \\ Tolerance, \\ Conflict Resolution \\ and Culture of Peace}

Draft for Testing

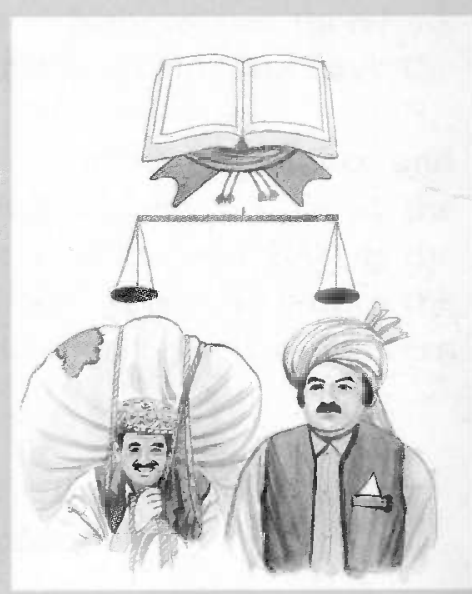

\section{Theme-4: Civic Responsibilities}

- The Truthful Boy

- Greed

- The Teacher and Sharif

- Penalty

- The Sickle and Harvest

- The Flood

- Zahra's Friendship with Hamida

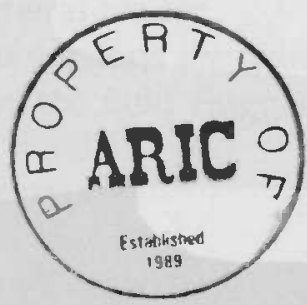

- The Treasure of Values

- Fereshta Changes her Mind 


\section{Preface}

Peace, it is now universally recognized is a pre-requisite for the socio-economic development of individuals, societies and nations. The United Nations has therefore, been striving from its very inception to bring about peace in the work, and save the future generations from the ravages of war.

Among other measures there is a need, to combat the growing intolerance and hatred, and promote a culture of peace, amity and goodwill among people at the national and international levels. The United Nations has declared the year 2000 as the International Year for Culture of Peace, and UNESCO as the Focal Agency to launch the programme. The choice seems most apt, for UNESCO's constitution reflects its concern for peace in the following words:

"That since war begins in the minds of men, it is in the minds of men that the defences of peace must be constructed."

Education, is a key area which could be effectively employed to grapple with fanaticism, religious and racial prejudices, violence and intolerance which seem to threaten the very fabric of our civilization and world peace.

Of all other countries, Afghanistan has suffered one of the worst socio-economic upheavals in recent times, on account of war and internal turmoil, and is in urgent need of peace so that conditions may normalise, refugees return to their homes, and people settle down to their daily routines once again.

Recognising therefore what has befallen the country, and the catalytic role that education can play in fostering a better understanding among the people, UNESCO Islamabad supported a process of developing reading materials for Afghan youth, especially students. A 10-day workshop was organized in April, 1999 in collaboration with AG BAS-Ed and participation of UNHCR. Twenty five Afghan educators and writers attending the workshop assisted in preparing suitable material in the form of essays, puzzles, poems, etc.

Fifty of these were finally selected on the basis of their themes, and are being published in Dari and Pashtu in the form of eight booklets in the present series. An attempt has been made to use everyday language to avoid problems of comprehension. Also, a racy style has been maintained to hold the interest of potential readers. The English version is for the general reader.

The Dari and Pashtu versions are being field tested. These will be further refined on the basis of feedback from the field. Suggestions are most welcome.

June, 2000

P. K. Kasaju

Director/Representative UNESCO, Islamabad 


\section{The Truthful Boy}

Baryalay lived in a hilly village with his widowed mother, and three sisters. He went to work in the city every day. He would go in the morning and return in the evening. Raining or snowing, this was his daily routine, and he kept it up to provide for his family.

Once he worked later than usual, and by the time he reached the forest, through which he had to pass to reach his house, night overtook him. The jungle was full of wild animals, and a few days earlier, Kala Lalay and his donkey had been attacked, and injured by wolves. So he decided to spend the night on the fringe of the forest. He found a cave by a big rock. He entered looking around cautiously lest there were harmful creatures inside. In one of the corners lay a big stone. He decided to move it aside to make room to lie down for the night. He pushed and jerked it several times. Finally, the stone moved and Baryalay could stretch his legs. Suddenly, he saw a hole under the stone. He put his hand into it carefully, and touching something, pulled it out. It was a clay pot full of gold coins.

"My days of poverty," thought Baryalay, "have ended". He was overcome with joy, and saw himself the owner of large tracts of land, houses, shops, cars and what not. He could now buy sheep and cattle, and looked forward to marrying a paragon of beauty. Then he went to sleep and saw in a dream an old man talking to him: "The treasure you have found and regarding which you are so full of joy does not belong to you. It belongs to all the people. Each citizen of the country has a share in it. If you take the treasure home, you shall violate the rights of all Afghans. O ! young man, give this fortune to the Government, which protects private and public property. It would be morally wrong on your part not to return this treasure to where it rightly belongs --- the Government."

The old man wanted to say something more but Baryalay woke up. He looked into the pot in daylight and found it full of gold. He recalled the advice of the old man, "Give this treasure to the Government."

He covered the pot with sand and took it to the Woluswal saying, "Sir, I have found treasure in a cave. I have brought it to you because it belongs to the public, and should be deposited with the Government".

The Woluswal was delighted to hear the news and sent his men with him to bring the treasure to his office. Later, he went to his village and told the whole story to the villagers after the Friday prayers, adding that Baryalay could have kept the gold, but instead chose to hand it over to the Government. Saying this he gave Baryalay a cash award.

Baryalay built a small house for himself out of the money he received, rented a small shop, and bought a bicycle. 
Woluswal spent the treasure on the building of an asphalt road to the bazar. A school and a clinic were added later.

He also established an office to help the farmers in getting loans, seeds, plants and fertilizers. The people of nearby villages made use of these facilities as well.

Baryalay's honesty thus helped in providing many civic facilities to the people of his area, brought them closer to each other, and helped in creating a peaceful and happy environment.

Let us not therefore forget, that it is the duty of all citizens to safeguard what collectively belongs to the nation, and ensure its protection and safety.

\section{Questions :}

- What is the moral of this story?

- Why did Baryalay hand over the treasure to the Government? 


\section{Greed}

Gul Lala returned to Afghanistan with his family and two sons, Baz Gul and Noor Gul. He asked his sons to go with him to meet the people in their village, and see what had happened to them since they had been away. "Let us first go to our cousin's house," he said, "because they seem annoyed with us."

When they reached the village they found it in ruins. It had been so badly damaged that they could not believe it was the same village, where they had once lived. There were no inhabitants and it seemed deserted. They were looking around when they heard a faint voice. Listening attentively, they followed its direction which took them to the shade of a wall, where a sick man was lying on a bedstead, burning with fever.

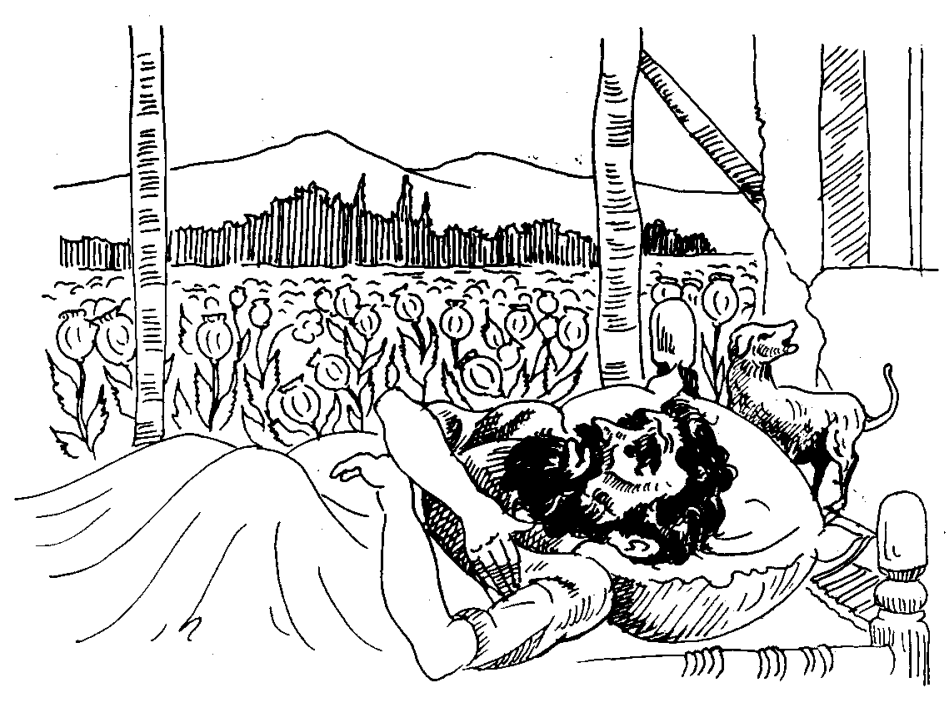

Gul Lala greeted his cousins and told them his sad story: "After you left, my entire family, except Torkham, was killed during bombardment on the village. Unfortunately, Torkham then started cultivating poppy. People advised him not to do so, for they feared the youth of the village would become addicted to the drug. He did not listen to them and our relations with the villagers became strained. In fact we were socially isolated".

"Furthermore, to make quick money Torkham began smuggling heroin, and left the village with opium three years ago, and I haven't seen him since. There are all sorts of rumours. Some say that thieves robbed and killed him. Others speculate he is languishing in some jail overseas. Nobody knows for sure what happened to him." 
"What do they make heroin from"? asked Baz Gul of his father.

"From opium," replied his father, adding: "So many people have become heroin addicts in Afghanistan. It is a pity they cultivate it."

"And what harm is caused by heroin?"

Gul Khan, the sick cousin explained: "Heroin and other drugs affect the lungs, cause respiratory diseases and ruin a person's health. These can also cause cancer. A drug addict leads a miserable life and dies in course of time."

"Can't something be done to stop the cultivation of opium?" asked Noor Gul.

"Well of late there has been some awareness, but we need to educate every one, especially the youth, of the harmful effects of heroin. Its cultivation must be stopped, and that is possible if people persuade those cultivating opium, not to do so. This would be no small service to the community, and the country."

\section{Question :}

- What are the harmful effects of cultivating opium? 


\section{The Teacher and Sharif}

Sharif is a sixth grade student. One day he came late to the class. "Sharif, why are you late today?" the teacher asked him. "My uncle," replied Sharif, "is a driver. He has recently come from Afghanistan with his vehicle. He did not know the local traffic laws and has hit another vehicle. The police have sent him to the lock up, where I had gone to see him. I am therefore, late for the class."

"Could you explain sir, what is meant by law?" asked Sharif.

"Law", said the teacher "is a rule enacted, or customary in a community, and recognized as enjoining or prohibiting certain actions, and enforced by the imposition of penalties. In a modern day state, laws are enacted by the legislative and government authority (i.e. the parliament or assemblies), implemented by the executive, and supervised by the judiciary (judges), in courts. All citizens, whether rich or poor, are equal before the law".

"What sources are used for framing laws?" asked another student.

"In our country," said the teacher, "the text of the Holy Quran, practices of the Holy Prophet (PBUH), Afghan socio-economic principles and conditions of society, are taken into account while framing laws. For instance, we should not injure a person's self-respect or dignity or assault him, or take away his goods or trespass on his property. Terrorism cannot, least of all, be condoned in any way. Most conflicts, scholars point out, arise when we show disregard for other people, and hurt their self respect. In other words, we should in no case, violate the chastity or honour of womenfolk, whoever they be, or encroach on the rights of other people, or usurp their property. God does not like oppressors. 'We created you from man and woman,' God has said and, 'grouped you into branches and tribes so that you may identify each other, but the most honourable among you are those who are the most God-fearing.' Yet in another verse it is said: 'They hosted for God's forgiveness and the paradise which is extended from the earth to the sky --- this paradise is promised by God to those God fearing persons in the condition of comfort or difficulty, who give alimony for God's sake, and suppress their anger and pardon the people.' As regards benevolence the Holy Prophet (PBUH) has said, 'the best amongst people are those who are benevolent.'" 


\section{Questions:}

- Who enacts laws in modern day states?

- Most conflicts occur because we show no regard for other people's views. Do you agree? 


\section{Penalty}

Some of the refugees were back home, while the others were expected soon. Therefore, reconstruction of villages and houses had to be expedited, land made cultivable and schools rebuilt. Meanwhile, the Jergah met on Fridays to settle land disputes, decide on marriage petitions, and remove bottlenecks if any, being faced by the NGOs, in the implementation of their projects.

Unfortunately, some people in their endeavour to get rich, the Jergah was told, were hunting and capturing birds (falcons for instance) illegally, and making good money by selling them. Others had been depleting the natural resources, by cutting down and selling trees, despite opposition by some of the villagers. Also, as some of the landowners continued to cultivate poppy, the NGOs had closed down their offices and left.

Increase in deforestation, it was further disclosed, had deprived the jungle of its fauna. There had also been murders on the sharing of trees.

That was not all. The Jergah was also informed, that the engraved stone of Malang Baba's grave, had been excavated, and carried away.

The Jergah decided to take the matter to the local Administrator, who complained to them about cutting of trees. "We persuade the humanitarian agencies to come and help us, but what they see here are only poppy farms and forest trees, being carried away on mules and all available means of transport. The bridge on the Noray River was not built, because it was feared, it would be used to transport wood cut illegally from here," he said.

"Let us impose penalties on the wrong doers," said Haji Bakhtiar from the lower village.

"We agree," said the other members of the Jergah present there, "Cutting forests, catching rare birds and animals and cultivation of poppy should be prohibited, and whoever violates these rules should be penalised promptly."

"Graves and shrines too," said another elder, "should not be desecrated, it's a shame we uncover the bones of our forefathers."

The council unanimously agreed to impose penalties for all the aforementioned offences.

\section{Questions:}

- Why are forests necessary for a country?

- How can forests be preserved in Afghanistan? 


\section{The Sickle and Harvest}

Anzer Gul from the upper village had two sons, Tawoos and Tela Gul. They had grown wheat in their land, and it was time to reap the harvest. Therefore, with sickles in their hands, they were on their way to their land, when they met Aslam Khan, who had lost both his eyes during the war. Using his cane he was walking briskly towards a huge cliff, under which a big river ran. "Stop Aslam Khan, stop!" they shouted. "You are heading towards the river, you'll fall." He was now only a few feet from the river and stopped. "What are you doing here?" they enquired, coming closer to him.

"I haven't a big brother or a son to help me, and it is harvest time. My neigbhour had helped me cultivate my land and now it is sowing time. Everyone, however, is busy and I am going to the lower village to ask for help. You know I am not rich, and people do not care for the disabled."

"Well let us reap Aslam Khan's wheat brother," Tela Gul suggested to Tawoos, "we can attend to our own crop tomorrow."

"Our wheat is ripe. The grains will scatter away. Should we leave our own work to attend to other people's duty?" replied Tawoos.

"He is no stranger," argued Tela Gul, trying to convince Tawoos, "he is a fellow villager. He has lost his eyes in the service of the country. It is people like him, who waged a relentless war against the enemy, and forced him to withdraw. This has enabled us to return to our houses once more. God Almighty has said in the Holy Quran: 'Help your Muslim brethren in good deeds.' Our Prophet (PBUH) has said that God will solve the problems of one, who makes an effort to solve the problems of another Muslim, in times of need."

"Then let us go and reap his wheat," replied Tawoos Khan, "before it gets too hot. People like him have certainly done great service to the country, by resolutely facing the enemy and forcing him to withdraw."

When the two brothers started reaping Aslam Khan's wheat, a few other young men joined in, and the harvesting was soon over. Aslam Khan thanked them all.

"You are our brother," they said in reply, "and it is one's duty to help disabled persons. Moreover, you have served the country nobly. May God enable us all to be of help to our fellow beings?" 


\section{Questions:}

- Who was Aslam Khan?

- Where was he going?

- Why did Tela Gul persuade his brother to reap Aslam Khan's crop? 
Since then, Faheem Khan is acclaimed as the hero of the village. Gulghutey too cannot forget the good turn he has done to her family, and has asked her children to treat him as an elder brother.

\section{Question:}

- What lesson do we learn from this story? 


\section{The Treasure of Values}

Man's capacity to learn is unlimited. It is the duty of parents, as well as teachers, to exploit their children's potential, and train them on the right lines so that, besides acquiring worldly knowledge, they become good and useful citizens. God Almighty has said:

"We created him (man) to be tested (by us). We made him so as to be able to hear and to see, and to be knowledgeable, and showed him the path. So, it is he who should choose his way to reach the height of humanity". (Surat Addahr Verses 2-3).

One of the most important values to be cultivated, are worshipping God and following His commandments. Any action performed to earn God's goodwill is akin to worshipping Him. In addition one must fulfil one's family obligations.

Acquisition of knowledge, it is said lays the foundation of sound reasoning, and thereby enables man to appreciate the importance of freedom, justice, love and worship.

The Holy Prophet (PBUH) has said that man's true friend is knowledge, and his worst enemy is his ignorance. And there is no better mode of worshipping than pondering and reflecting. Acquisition of knowledge and studies brighten intellect. God it is said, has sent two prophets to each man. One is internal, the human intellect, and the other external, who reveals His messages to human beings. To achieve happiness, one should supplement the instructions of the inner prophet, with those of the external one.

One should therefore, listen to the instructions of sages and individuals experienced in the ways of the world, and learn to live in harmony and love with one's fellow beings. Violence in any form has seldom served any cause, and should be shunned under all circumstances.

A wise man has said that if you answer your enemy in a bitter tone showing hostility, ill-will never ends. Therefore, he loved a man even if he harmed him.

Restraining oneself from doing harm to others is not enough. One should make an effort to do others a good turn, whenever one can. The analogy of water best illustrates the point: it makes its way through rocks and mountains.

A sage often advised his followers thus: "Be tolerant, gentle, and kind to your fellow beings. Avoid telling lies, do not deprive anyone of life, or take what is not yours, be firm in exercising self-discipline, answer bad deeds with good ones, and if anyone abuses you, remain silent." 


\section{Questions:}

- What advice did the sage often give to his followers?

- Studies brighten intellect. What does this mean? 


\section{Fereshta Changes her Mind}

"There was a time," says Fereshta, "when I thought my language was the best of all languages. I also believed that the traditions of my family and relations were superior to all others. Further, I had a notion that the clothes worn by the inhabitants of my birthplace were more attractive and fascinating, than those worn by others."

"However when I joined the university and met girls from other parts of the country, my outlook changed altogether. I saw that girls from the cities and overseas, who spoke different languages and dialects, had different tastes in matters of dress, often as good or perhaps better than mine; also their manners were polished and they followed customs that seemed well worth imitating.

"I now like people who are broad minded and do not think themselves superior to others. I mix well with my class fellows, and we study in a very congenial and harmonious atmosphere.

"I wish we were taught about the good aspects of culture and customs of other nations and tribes, to enable us to appreciate and understand them better. We should not form one-sided, opinions or make comparisons which may lead to ill-will and bitterness. After all it is variety in dresses, customs, languages, colours and life styles of people that makes life on this planet exciting and colourful." 


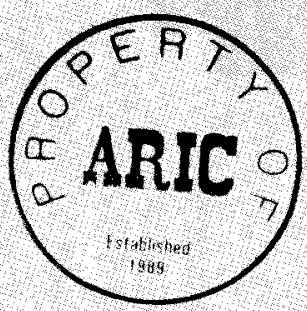

United Nations Educational, Scientific and Cultural Organization

First Floor, Saudi Pak Tower P. O Box 2034, Islamabad, Pakistan

Tel. $(92-51) 829452-829453-813308 \mathrm{Fax}(92-51) 825341$

E-mail:unesco@isb.compol.com 
Afghanistan Series on

Tolerance,

Conflict Resolution

and Culture of Peace

Draft for Testing

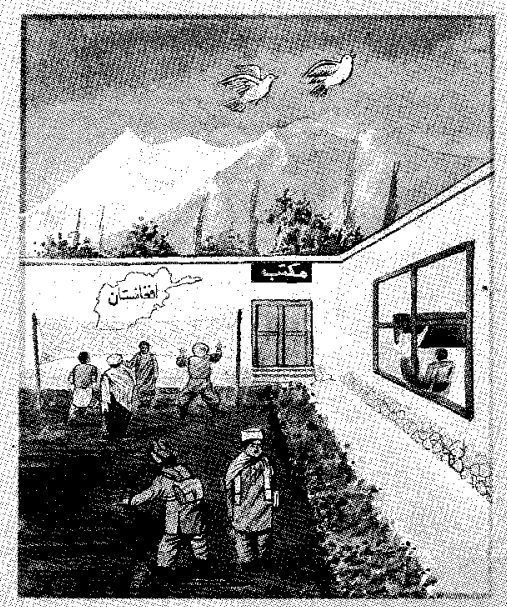

Theme-3: Peace and Non-Discrimination

- Conversation Among Friends

- Progress is Possible only in times of Peace

- Peace and Islam

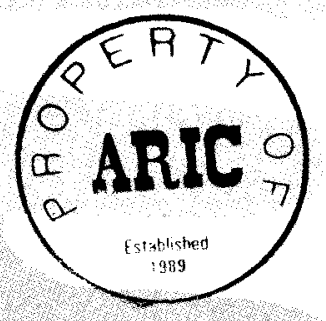




\section{Preface}

Peace, it is now universally recognized is a pre-requisite for the socio-economic development of individuals, societies and nations. The United Nations has therefore, been striving from its very inception to bring about peace in the world, and save the future generations from the ravages of war.

Among other measures there is a need, to combat the growing intolerance and hatred, and promote a culture of peace, amity and goodwill among people at the national and international levels. The United Nations has declared the year 2000 as the International Year for Culture of Peace, and UNESCO as the Focal Agency to Iaunch the programme. The choice seems most apt, for UNESCO's constitution reflects its concern for peace in the following words:

"That since war begins in the minds of men, it is in the minds of men that the defences of peace must be constructed."

Education, is a key area which could be effectively employed to grapple with fanaticism, religious and racial prejudices, violence and intolerance which seem to threaten the very fabric of our civilization and world peace.

Of all other countries, Afghanistan has suffered one of the worst socio-economic upheavals in recent times, on account of war and internal turmoil, and is in urgent need of peace so that conditions may normalise, refugees return to their homes, and people settle down to their daily routines once again.

Recognising therefore what has befallen the country, and the catalytic role that education can play in fostering a better understanding among the people, UNESCO Islamabad supported a process of developing reading materials for Afghan youth, especially students. A 10-day workshop was organized in April, 1999 in collaboration with AG BAS-Ed and participation of UNHCR. Twenty five Afghan educators and writers attending the workshop assisted in preparing suitable material in the form of essays, puzzles, poems, etc.

Fifty of these were finally selected on the basis of their themes, and are being published in Dari and Pashtu in the form of eight booklets in the present series. An attempt has been made to use everyday language to avoid problems of comprehension. Also, a racy style has been maintained to hold the interest of potential readers. The English version is for the general reader.

The Dari and Pashtu versions are being field tested. These will be further refined on the basis of feedback from the field. Suggestions are most welcome.

June, 2000

P. K. Kasaju

Director/Representative

UNESCO, Islamabad 
We express our gratitude to the following Afghan authors for their contribution to this serial:

- Abdul Ahmed Amoozgar

- Ghulam Dastgir Amanzai

- Abdul Qadir Imami Ghuri

The opinions expressed in this series represent the views of the authors, not of UNESCO. 


\section{Conversation Among Friends}

One day Ahmad, Asad and Mahmood, sitting beside a stream, were recounting their losses, bitter misfortunes and experiences of the war. One of them described how the war had claimed the lives of his dear ones: young, educated sons.

The second lamented at having lost all his property, while the third complained, that he could not afford looking after all the orphans and widows, he now had on his hands.

Ahmad suggested that they pray to God, for peace to return to their land. "Presently we need peace," he emphasized, "as badly as a parched desert needs rain. If rain does not reach such a desert in time, the thirsty travellers faint or die. Likewise, if peace is not restored soon to our country, whatever remains of our material and spiritual values, will also erode away."

"The long war," decried Asad, "has turned our country into a ruin. We have lost the flower of our youth, and the cream of our scholars and religious divines. Our industrial plants and factories have been abandoned, and fallen into disuse. Children no longer go to schools, and economic activity having virtually come to a standstill, is causing the masses to groan under the burden of soaring prices, and frequent shortages of necessities of life. We want peace now than ever before."

"The longer the war continues," observed Mahmood, "the greater will be the destruction. Already our resources are so severely depleted, and stretched that the country cannot withstand any more strain. Poverty is widespread, there is intervention by other countries in our affairs, and the increasing number of widows and orphans are adding to our difficulties, while the scale of social corruption is on the rise. Peace like oxygen has therefore become indispensable for our survival."

Maintenance of harmony and peace, in an Islamic Socicty, let us not forget, are among the injunctions of the Holy Quran. Our Prophet Muhammad (PBUH), therefore, stressed the need for peace in an Islamic polity.

We should bear in mind that:

1. Peace is "Water for life."

2. Tolerance and patience strengthen human character.

3. Self-denial is the key to progress.

4. Knowing one's self means knowing God. 
5. Success lies in steadiness and constancy.

6. No spiritual or material development is possible without peace.

7. Patience appears bitter but has a sweet outcome. 


\section{Progress is Possible only in times of Peace}

Our social sciences teacher used to say, "Progress of all kinds, including a better life, is possible only in peace time. If there is no peace, talking of development, and prosperity, becomes meaningless".

The other day I met Mahmood, an old classmate driving a taxi. We had been studying together in school at the elementary level. It was touching to see him now employed thus, because he came of a rich family, in our parish. After completing his secondary education, he had joined an art institute, and graduated from there with distinction.

He had a fine taste in all matters, and was progressive and forward looking. Completing his education, he had started working in his father's factory, located in the industrial sector of the town.

When I had met him a few years earlier, he had progressive ideas and talked enthusiastically about how he intended to raise production, and improve quality by arranging training courses for the workers, to enhance their technical skills. Also, he had plans for organizing literacy courses for their families.

Now, while shaking his hand I looked baffled. "Dear Mahmood," I said, "I hope I am not mistaken, you are my classmate and friend of school days". "Yes," said he, embracing me warmly, "I am the same Mahmood, your old friend."

When I enquired about his father, and how his factory was operating, he became dejected and explained, "While there was peace, law and order, we were doing well, but then the robbers attacked the city. They killed my father, ransacked the factory, carried away the machinery, and set the building on fire. I could hardly have suffered more grievously. My family and I eventually landed here. As I had neither money, nor hope of securing a job to sustain me, I thought it best to start working as a taxi driver, being a good hand at driving." odds."

"It is a pleasure," I said to him," to see you doing your best, despite all

After he had left I ruminated for sometime on the vicissitudes of life, and the sad plight of my country and country men, but then my thoughts turned to what the social sciences teacher had said about progress, development and peace. 


\section{Peace and Islam}

(In the light of Quran and Prophetic Traditions)

Human society, it is said, is akin to human body. When an organ of the human body is afflicted with disease, or hurt in any other way, the whole body suffers. If, for example, a foot or an eye or a hand fails to function, the order and harmony of the whole body is disrupted. The Holy Prophet (PBUH) has explained this scientific fact as follows:

"The faithful in relation to love and affection, sympathy and mercy, make one organic whole (body) in a way that if one organ is affected, all the others feel the impact and become sickly."

The relation of Muslims to each other, he is also reported to have told his followers, is like the bricks in a building that support each other, and make the building strong and solid.

Islam is thus called the religion of peace and security, a religion which has been tailored to fit a man's nature. The word has its roots in Arabic (salamat meaning security, safety and health). It thus opposes violence, pain and disorder.

Our Creator, emphasizing the concept of brotherhood for all Muslims, has said, "No doubt, the faithful are brothers" (Hujarat, 10).

This is indicative of the fact, that society cannot survive, if there is no peace and security, among its members. Therefore, says Allah: "Fear God and make peace among yourselves and obey God and His Prophet, if you are truly faithful" (Anfal 11). The Almighty, therefore looks upon peace as a sign of fearing Him, and a manifestation of piety and obedience to Him. The need for maintaining peace, is therefore stressed. "If there is a conflict," says the Holy Quran, "between Muslims, make peace among them, for they are your brethren, and fear God, and be pious so that you are pardoned" (Hujarat 10).

God tells us also that, "Peace is a blessing," and further instructs the faithful not to treat even the non-Muslims with severity. "When the (nonMuslims) incline towards peace, get ready to make peace with them, for war is not the aim of Islam, except if it be the means for maintaining peace and justice. If this aim is achieved through peaceful means, there is no need to wage war."

The Prophet Muhammed (PBUH) is reported to have asked his disciples, "Should I inform you of something that is better than fasting and giving alms?" "Kindly do so," they entreated. "Then make peace among yourselves, because God will bring peace among Muslims on the day of resurrection", and added that a true Muslim was one from whose hands and tongue, the other Muslims were safe.

The above verses and Prophetic traditions all illustrate, the importance Islam attaches to peace, and show that it is a religion of harmony, security and 
peace. It opposes war, needless conflict, and animosity among Muslims, for only thus can the foundation of Muslim brotherhood be laid.

The Prophet of Islam adhered strictly by the precepts he preached.

The most striking example is that of the treaty he signed with the Jews. God has said of this treaty: "With the infidels that you signed the treaty and they did not break it, and did not support others against you, keep it with a durable time because God loves pious people..." (Tawbah, 4). 


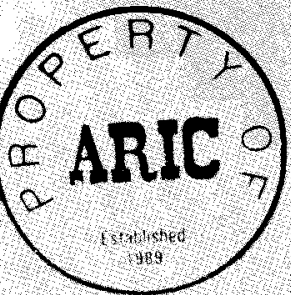

United Nations Educotional, Scientific and Cultural Organization

First Floor, Saudi Pak Tower P. O Box 2034 , Islamabad, Pakistan Tel: $(92-51) 829452-829453-813308$ Fax: $(92-51) 825341$

E-mail:unesco@isb.compol.com 
Afghanistan Series on

Tolerance,

Conflict Resolution

and Culture of Peace

Draft for Testing

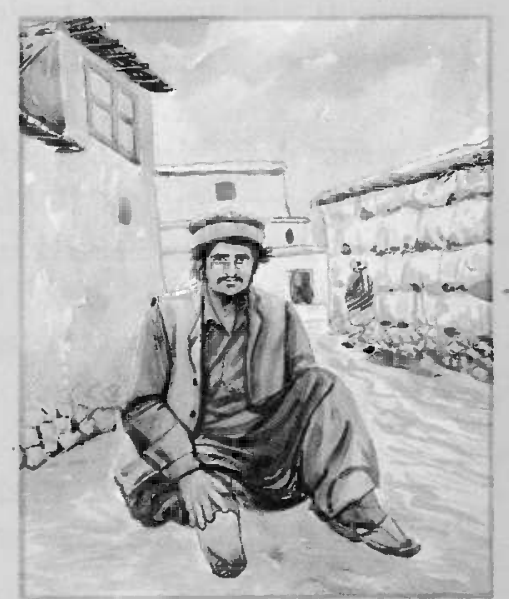

Theme-2: Understanding Non-Violence

- Will There be an End to Violence?

- Hudaibiya Peace Accord

- Why are We so Senseless?

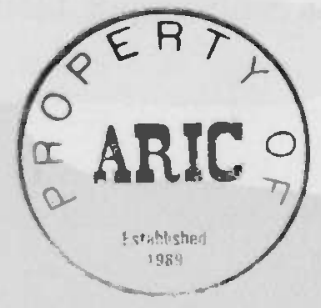




\section{Preface}

Peace, it is now universally recognized is a pre-requisite for the socio-economic development of individuals, societies and nations. The United Nations has therefore, been striving from its very inception to bring about peace in the world, and save the future generations from the ravages of war.

Among other measures there is a need, to combat the growing intolerance and hatred, and promote a culture of peace, amity and goodwill among people at the national and international levels. The United Nations has declared the year 2000 as the International Year for Culture of Peace, and UNESCO as the Focal Agency to launch the programme. The choice seems most apt, for UNESCO's constitution reflects its concern for peace in the following words:

"That since war begins in the minds of men, it is in the minds of men that the defences of peace must be constructed."

Education, is a key area which could be effectively employed to grapple with fanaticism, religious and racial prejudices, violence and intolerance which seem to threaten the very fabric of our civilization and world peace.

Of all other countries, Afghanistan has suffered one of the worst socio-economic upheavals in recent times, on account of war and internal turmoil, and is in urgent need of peace so that conditions may normalise, refugees return to their homes, and people settle down to their daily routines once again.

Recognising therefore what has befallen the country, and the catalytic role that education can play in fostering a better understanding among the people, UNESCO Islamabad supported a process of developing reading materials for Afghan youth, especially students. A 10-day workshop was organized in April, 1999 in collaboration with AG BAS-Ed and participation of UNHCR. Twenty five Afghan educators and writers attending the workshop assisted in preparing suitable material in the form of essays, puzzles, poems, etc.

Fifty of these were finally selected on the basis of their themes, and are being published in Dari and Pashtu in the form of eight booklets in the present series. An attempt has been made to use everyday language to avoid problems of comprehension. Also, a racy style has been maintained to hold the interest of potential readers. The English version is for the general reader.

The Dari and Pashtu versions are being field tested. These will be further refined on the basis of feedback from the field. Suggestions are most welcome.

June, 2000

P. K. Kasaju

Director/Representative UNESCO, Islamabad 
We express our gratitude to the following Afghan authors, for their contribution to this serial:

- Ms. Faiza Mehrabi Barak

- Ms. Aysha Aziz

- Imami Ghuri

- Abdulqadir

The opinions expressed in this series represent the views of the authors, not of UNESCO. 


\section{Will There be an End to Violence?}

Murid drank his cup of tea and felt refreshed. Looking around he saw some holes on the walls of the room. "Why are there holes on this wall?" he asked his mother. "My son," she replied, "Kabul has been virtually destroyed because of the internecine conflict going on. Thousands of people have been killed and scores of houses, schools, mosques, factories and power stations damaged, or even razed to the ground. Their equipment is being sold as junk. You must have noticed the Pul-i-Charki factory ruins on your way home. They have been the scene of much fighting. At this point the son of the landlord entered the room and said, "Some criminals are going to be punished at the Ghazni Stadium tomorrow."

"Mother, what did that man say? I could not follow him. Who are the criminals?" he asked after the young man had left.

"Well you should have been taught that at school. A criminal is an offender who breaks the divine, or man made laws. He thus poses danger to the life, security and peace of the citizens. Those who have committed heinous crimes shall be punished publicly tomorrow."

"What have these people done mother? What sort of punishment shall be meted out to them?"

"Well if they have stolen people 's property, killed some one, or committed rape, the prescribed penalty shall be imposed".

"Are not these punishments too harsh mother ?" asked Murid. "Is it necessary to punish these people?"

"Well if the criminals are not punished, then security, peace and lives of the public are endangered. Moreover, such punishments serve as deterrents and warning to others".

"God has ordained in the Holy Quran that such penalties should be awarded. Islam has its own laws in this regard."

"What is retaliation?" enquired Murid.

"Qisas in the Holy Quran," explained the mother, "is equity which means punishment should be awarded in proportion to the crime committed. The verse 178, Surah Al Baqarah revealed in this connection says":

'O! Ye who believe! The law of equality is prescribed to you in cases of murder; the woman for the woman, the free for free, the slave for slave. But if remission is made by the brother of the slain, then grant any reasonable demands, and compensate with handsome gratitude. This is a concession and a mercy from your Lord. After this whoever exceeds the limit shall be in great chastisement'.

"Islam reveals too," she further explained, "that all are equal before the law, irrespective of the office they hold, or their caste, colour or creed. To grant 
remission, says the Holy Quran, is better than seeking revenge, and advises us to solve all our conflicts, through reconciliation and dialogue. There is not so much pleasure in revenge, the Holy Book informs us, as there is in remission, because the latter reflects valour and generosity."

"Could you explain, what is revenge mother?"

"Well revenge is retaliation for an offence or injury."

"If a person is unable to take revenge, mother and forgives the other side, what happens then?"

"If a person is in a position to take revenge, but remits instead, he is indeed a kind and generous soul."

"What is remission?" asked Murid.

"Remission is tolerance," explained the mother, "against other people's excesses and violence. If one is not tolerant in his daily life, at school, market, mosque, at home or in his job, he is likely to pick up arguments and quarrels every now and then. Therefore, our Prophet had advised the Muslims to be tolerant, no matter what difficulties they may have to face. Let me tell you a story. When our Prophet Muhammed (PBUH) lived in Mecca, the Meccans intended to martyr him. They molested him, forcing him to migrate to Mecca. When Mecca was conquered, the Prophet forgave them all, much to their surprise, for they expected to be put to death. 'Go safely,' he had said, 'there is no punishment for you'."

"Do you know any person who, although being in a position to take revenge, has remitted any body?" enquired the son.

"The Holy Prophet Muhammed (PBUH)," said the mother, "as is wellknown, had intervened to avert a quarrel over grazing of cattle, between small boys and shepherds in Mecca, which could have sparked off hostilities, resulting in much bloodshed, between the two tribes. It was very hot in Mecca. The pastures were full of herds and small boys took care of them. Shepherds had also been hired for the purpose, while others owned the herds. Only one area, in the shadow of a mountain was green, as the meadows had dried up. A quarrel ensued, as everyone wanted to graze his sheep there. The children ran to their guardians, complaining that they had been abused and insulted by the shepherds. This could have provoked a war on account of old grudges. But the Holy Prophet (PBUH), who reached the scene, intervened to say that the boys were lying, and their mothers and fathers had not been abused by the shepherds, as alleged. The people at that scattered, regretting that their boys had told lies, and upbraided those who wanted to stir up trouble. 'Help ye one another in righteousness and piety,' says the second verse of Al-Maidah, 'but help ye not in sin and rancour.' The Muslims, this means, should stop a person if he goes beyond the limits of justice prescribed by religion, to take revenge. Halima, the Prophet's foster mother had sacrificed four camels to feed the poor on this account. This was a message to the Muslims to solve their conflicts through dialogue and negotiations." 
If one wants to be a good person, the mother advised Murid, one should remember the following points:

1. Love God, your people and your country.

2. Act with remission towards those who harm you.

3. Be a peace-maker. Wish well to all.

4. Be moderate towards your foes, generous to your friends.

5. Be a judge of yourself.

6. Accept criticism.

7. Be brave.

8. Think before you make a promise, but make haste in fulfilling it.

9. To achieve your ends do not ruin others.

\section{Questions:}

- What do you learn from the above conversation?

- How can you ușe information you acquire in practical life? 


\section{Hudaibiya Peace Accord}

Peace ensures a calm and tranquil life for man. God Almighty has therefore, instructed the faithful to live in harmony and accord with one another. Despite this, peace is at times, disturbed and wars break out.

When the Holy Prophet (PBUH) declared himself to be the Messenger of God, the Quraish left no stone unturned to thwart his aims. But despite incessant provocation, the Muslims guided by their Prophet, exercised great forbearance, and preferred the path of peace. The Hudaibiya Peace Accord is often cited to illustrate the point.

The Holy Prophet (PBUH), it is reported, had a dream in 6 A.H. that he had entered the sacred Mosque at Mecca. He thereupon decided to go there to perform Umra (the minor pilgrimage).

Accordingly, with fourteen hundred unarmed companions, he set out to Mecca for the pilgrimage. When the non-Muslims came to know of it, they decided not to allow him and his companions to enter the city. He therefore, halted at Hudaibiya at a distance of about three miles, to inform the Quraish that they had come unarmed, and wished to enter Mecca for performing Umra.

The messenger sent by the Prophet did not return, therefore another was sent. As he too did not return, Hazrat Usman was sent. He too, was detained by the Quraish, and a rumour spread that he had been killed. The Holy Prophet (PBUH) at that collected his followers near the oasis of Rizwan, and placed them under oath, that they would lay down their lives in the name of Allah.

As the Muslims were getting ready to proclaim war against the murderers of Usman, they suddenly saw a man approaching from Mecca. A man shouted, "I know him, he is Sohail Bin Amer!" He told the Prophet so. The Prophet said, "If that be so, the people of Mecca desire to make peace, for Sohail being a sensible man, would not be interested in war."

Sohail addressed the Prophet thus: "O! Muhammad, we heard the Muslims owing allegiance to you. The people regret the violence done by their leaders to you. Usman is alive and he will arrive soon. I have been sent to pave the way for peace."

The Prophet who always preached peace and reconciliation, and held the House of God in high esteem, started negotiations with Sohail, and an accord was reached on the following terms:

1- There shall be a cease-fire for a period of ten years. No covert or overt operation shall be undertaken by either side.

2- If a person from among the Quraish takes refuge with the Muslims, without the permission of his guardian during this period, he will be returned to the Quraish, but if a Muslim 
goes over to the Quraish, they will not be obliged to return him .

3- The Arab tribes may sign treaties with either party.

4- The Muslims shall go to Mecca for pilgrimage the next year, and spend three days there. They shall not carry weapons, other than one sheathed sword each. The citizens of Mecca shall evacuate the city for the Muslims during these days.

5- They would not take any Muslim from Mecca with them, nor stop any Muslim from staying in Mecca.

A number of Muslims did not like the treaty, and felt displeased thinking they had been outwitted. They asked questions of the Holy Prophet (PBUH) and seemed apprehensive of the results of the treaty. But the Holy Prophet (PBUH) while trying to allay their fears, abided by its terms. Refugees accordingly were sent back to Mecca.

The treaty, however finally ended the atmosphere of hostility, and a large number of unbelievers accepted Islam.

We have meanwhile, seen treaties signed between Afghans, in the most

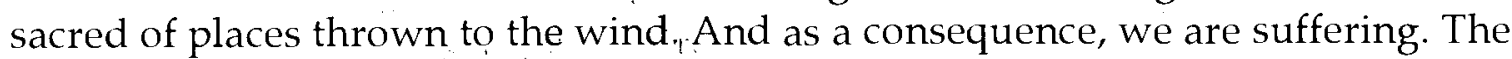
Holy Prophet (PBUH) kept his word, and adhered strictly by the treaty executed with the infidels, while we have broken promises made with our Muslim brethren on many occasions. 


\section{Why are We so Senseless?}

Shikeb and Hanif had been classmates at one of the well-known schools in our historical, and at one time, beautiful city of Kabul.

While in classes eleven and twelve, they had been on school excursion trips, visited various sites of historical and tourist interest (Baghlan, Ghor, Mazar-i-Sharif, the Harirod river, the statues of Buddha in the fire temple, Sharee-Ghulghula, the ancient civilization of Balkh etc.), and found that Afghanistan had a rich and diverse cultural past. They had enjoyed the breath taking scenery, the mountain ranges, newly built roads, and noted with interest the industrial establishments, cultivated lands and agricultural farms humming with life and activity.

Now returning after several years from overseas, where he had gone for higher studies, Shikeb found that everything had changed for the worse. Kabul lay desolate and deserted, as if it were a haunted city. The once friendly and social Afghans, seemed to have turned into warring groups and wild beasts, eager to shed each other's blood. Thousands of families had been rendered homeless, while others had fled the land in panic, taking refuge in the neighbouring countries. Those who for some reason, could not leave the country, including the disabled, orphans and widows presented a pitiable sight, begging in the streets of Kabul. Civilization, it seemed, was about to come to an end.

Hanif invited Shikeb to dine with him one day, and explained how the whole social fabric had been torn asunder by violence. The people it seemed, had lost all reason.

"While abroad, I used to get news now and then, but could you elaborate on this violence?" said Shikeb.

"Violence in our case," explained Hanif, "has been in the nature of a person or party imposing its will on the others, using force. This has resulted in bitter conflicts disrupting normal life, and bringing untold miseries to the people. For the rest, you have seen with your own eyes. The foundation of our country has been rocked, families split and we no longer bear semblance to a united nation.

Let us not forget that as Muslims we should be guided by the precept of Islam. God Almighty had enjoined our Holy Prophet (PBUH) to remit the mistakes of his followers and consult with them. Thus soft-heartedness, remission and consultation were the most striking personality traits of our Prophet, whose footsteps we ought to follow."

"God also loves those who help others," said Shikeb, "suppress their anger, remit sins and are virtuous. Muslims, moreover being brothers in faith, are forbidden to resort to violence against one another, and have been advised 
instead to act in the light of logic and reason, while settling issues. If we had followed the teachings of Islam, we would not have been in such dire straits."

"The unkindest cut of all," he resumed after reflecting a little, "is that we all know racial, tribal, linguistic, religious or regional conflicts, or for that matter any discrimination, is contrary to the teachings of Islam. The Holy Prophet (PBUH), had warned his followers: 'Do not become infidels after me by cutting each other's throat'."

"What in your opinion," asked Shikeb, "have been the main causes of violence so that by identifying them, we may put a stop to it?"

"The problem," replied Hanif, "is rather a complicated one. There are numerous factors, but desire for revenge, illiteracy, ignorance, egoism, ethnocentrism, desire to monopolize power, achieve fame, acquire wealth, and reluctance to abide by Islamic precepts can be identified as the major causes."

"We should in that case, do all within our means," said Shikeb, "to create awareness among people about these issues, so that Afghanistan may once again become a haven of peace and tranquillity and a tourist's paradise." 


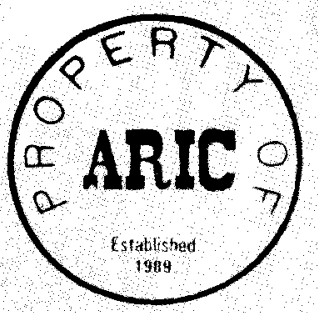

United Nations Educational, Scientific and Cultural Organization

First Floor, Saudi Pak Tower P.O.Box 2034, Islamabad, Pakistan

Tel: $(92-51) 829452-829453-813308$ Fax $(92-51) 825341$

E-mail: unesco@isb.compol.com 
Afghanistan Series on

Tolerance,

\section{Conflict Resolution \\ and Culture of Peace}

Draft for Testing

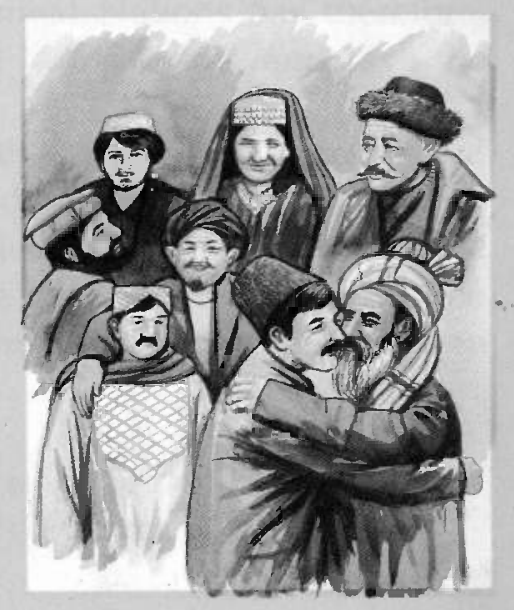

Theme-1: Tolerance

- The Story of Aslam

- The Miracle of a Necklace

- The Value of Tolerance

- I Think

- How Peace Disappeared from our Village

- Conflicts Should be Settled

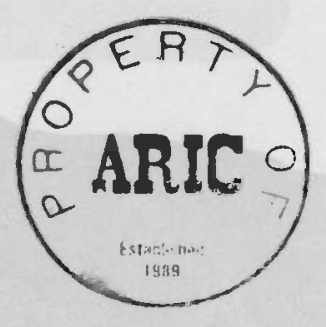




\section{Preface}

Peace, it is now universally recognized is a pre-requisite for the socio-economic development of individuals, societies and nations. The United Nations has therefore, been striving from its very inception to bring about peace in the world, and save the future generations from the ravages of war.

Among other measures there is a need, to combat the growing intolerance and hatred, and promote a culture of peace, amity and goodwill among people at the national and international levels. The United Nations has declared the year 2000 as the International Year for Culture of Peace, and UNESCO as the Focal Agency to launch the programme. The choice seems most apt, for UNESCO's constitution reflects its concern for peace in the following words:

"That since war begins in the minds of men, it is in the minds of men that the defences of peace must be constructed."

Education, is a key area which could be effectively employed to grapple with fanaticism, religious and racial prejudices, violence and intolerance which seem to threaten the very fabric of our civilization and world peace.

Of all other countries, Afghanistan has suffered one of the worst socio-economic upheavals in recent times, on account of war and internal turmoil, and is in urgent need of peace so that conditions may normalise, refugees return to their homes, and people settle down to their daily routines once again.

Recognising therefore what has befallen the country, and the catalytic role that education can play in fostering a better understanding among the people, UNESCO Islamabad supported a process of developing reading materials for Afghan youth, especially students. A 10-day workshop was organized in April, 1999 in collaboration with AG BAS-Ed and participation of UNHCR. Twenty five Afghan educators and writers attending the workshop assisted in preparing suitable material in the form of essays, puzzles, poems, etc.

Fifty of these were finally selected on the basis of their themes, and are being published in Dari and Pashtu in the form of eight booklets in the present series. An attempt has been made to use everyday language to avoid problems of comprehension. Also, a racy style has been maintained to hold the interest of potential readers. The English version is for the general reader.

The Dari and Pashtu versions are being field tested. These will be further refined on the basis of feedback from the field. Suggestions are most welcome. 
We express our gratitude to the following Afghan authors, for their contribution to this serial:

- Ahmed Takal

- Ghulam Dastgir Amanzai

- Syed Mohammad Ibrahim Bamyani

The opinions expressed in this series represent the views of the authors, not of UNESCO. 


\section{The Story of Aslam}

Perhaps you have heard the Pushto proverb, which says, "Speak once and listen twice". This means, if we want others to listen to us, we should also have the patience to hear what they have to say.

Presently, I am going to narrate a story from my childhood, which should be of interest to you.

I had a friend Aslam, who was very fond of talking, and would not listen to others, or to put it in another way, "he put both his feet in one shoe." But there was no one who could guide and advise him. When he wanted us to play "ghortsay" (a traditional national game of children in Afghanistan), we would comply with his wish, but if we expressed a similar desire, he would flatly decline saying, "No we should go swimming". In short, he did not care much about other people's feelings.

At first, we put up with what he did or said, but in the course of time he became irritating. He would now insist upon having his own way. The more we opposed him, the more unyielding he became. It mostly happened that neither of our two parties would accept what the other proposed. So we became dispirited, and did not play together. At times, instead of playing and enjoying ourselves we would be quarrelling, calling one another names. This often ended in a fight or we simply went home.

Time passed, and as I have said we became fed up with Aslam's behaviour. One day Kabir, one of my friends said, "Aslam is extremely selfish. We cannot play because of him. I won't play with him any more. If I decide to go for swimming or playing, I'll do so without Aslam. If any of you wants to join me, he may come with me". Three of my friends joined him, but I did not.

I told Aslam, "Look you always insist on having your own way, and don't listen to others. You still have time. Let's not be self-willed but hear what the others have to say."

Aslam ignoring my advice retorted angrily: "Get lost. All of you have joined against me. You know nothing and want me to listen to your nonsense."

On hearing this, I was annoyed and joined Kabir and the others. We now played games happily, as we wished. Each of us had a say, and none could force his will on the others. Aslam would often sit in a corner and watch us play. Nobody liked playing with him. So he became sullen and dejected because of his own doings.

Time passed. Aslam was isolated and would not leave his house, out of sheer anger. He was forgotten. One day we heard he, along with his family, had left for some unknown place. We did not see him thereafter, but if anyone talked too much and did not listen to the others, we would say, "Aslam, speak once and listen twice. Don't insist on only what you wish." 
When someone did not agree with the others, we would bid him not to behave like Aslam who was annoyed, when someone said no to him.

\section{Questions:}

- Why is it important not to be self-willed?

- What are the advantages of being a good listener? 


\section{The Miracle of a Necklace}

One afternoon, the Holy Prophet Muhammed (PBUH) was sitting with his followers after offering his prayers, when a gray-bearded, seemingly weak and poor man, entered the mosque. His appearance showed that he had walked a long distance, and was tired.

"I am poor, I have neither clothes nor anything to eat," he explained on arrival. The Prophet replied: "Presently I do not have anything to give you, but I will send you to someone, who will certainly help you. That person is very close to God and his Prophet." He then asked Hazrat-e-Bilal to guide him to Fatima's* house, adding that providing guidance for getting help is also helping.

The old man on reaching Hazrat-e-Ali's house said, "Peace be upon you!"

Ali replying befittingly, enquired who he was. The man said, "I am very old and needy. I had gone to the Holy Prophet (PBUH), and asked for help. He has sent me to you!"

The grandsons of the Prophet, Hazrat-e-Hasan and Hussain had been hungry for the last three days, and the Prophet knew that. Fatima, the Prophet's daughter looked around, but could not find anything to give him. So she brought the skin of a sheep, on which Hasan and Hussain used to sleep. She gave it to him saying, "Take this, God solves all difficulties".

The old man said, "O Prophet's daughter! I am starving from hunger, and you are giving me a sheep's skin. Can I possibly eat this?"

Hearing this, Fatima brought a necklace, which she had received as a gift and gave it to him. The old man taking the necklace, went back to the mosque, and said, "O Prophet of God, your daughter gave me this necklace to sell, and said that God solves all problems."

The Prophet wept and said, "Truly God solves all problems, because the lady of the two worlds, has given you her necklace."

Ammar, one of the followers of the Prophet, sought his permission to buy the necklace. The Holy Prophet (PBUH) said God will not punish the buyer of this necklace. Ammar then turned to the old man, and enquired, for how much he would sell the necklace. "For one meal, a suit of clothes and a sum by which I may reach home," the old man replied.

"I will feed you to your fill, provide you clothes and give you sufficient money to reach home," Ammar assured him. He then took the old man to his house, and did as he had promised, as he still had with him, a part of his share of the spoils, from the war of Khyber.

The old man went back to the Prophet, who asked him if he had had his food and clothes. The old man said, "Yes. I am contented now."

\footnotetext{
* Fatima - daughter of the Holy Prophet Muhammad (PBUH).
} 
Ammar then sent Sah, a slave with the necklace to the Holy Prophet (PBUH), as a gift.

The Holy Prophet (PBUH) sent the slave to Fatima. She took the necklace and set the slave free.

The slave laughed while leaving the house as a free man. "Why do you laugh?" Fatima asked him. "To thank the necklace," he said, "for it has fed an empty stomach, clothed a naked body, made a needy man contented, set a slave free, and finally returned to the neck of its owner."

\section{Questions:}

- Why did the Prophet send the old man to Fatima's house?

- How did the necklace go back to its owner?

- Do you know the meaning of generosity? 


\section{The Value of Tolerance}

Whenever you find that you cannot get on well with your friends, people in the community, or your family members, just think over what makes individuals honoured, liked and respected. You will then discover that people are liked or disliked, because of their personality traits and behaviour towards others. For instance, you may have heard that a person is truthful, and is therefore admired, or generous and therefore, should be respected. Or, a man is praised because he is brave and helps others.

The story narrated here is a story not of an ordinary man, but the Holy Prophet Muhammad (PBUH), to see what sort of a personality he had.

Once, a number of elders from the tribe of Hawazen - tribe of the Prophet's foster uncle, who had converted to Islam - came to him and said, "There are your foster sisters and aunts among the captives. Give instructions that they be set free."

The Prophet said he was ready and willing to free the prisoners, who had come as his share and that of Abu Talib's family, but as regards the shares of other Muslims, they would decide for themselves. He asked them to make a request to the people about what they desired, after the prayers in the mosque. On his part, he would also ask them to give away their parts as well.

The representatives of the Hawazen tribe did as advised by the Prophet. Following his example, the other Muslims gave away their shares as well, and thus all the captives were released. With such affection shown towards them, the Hawazen converted to Islam.

We see in this and several other cases, that Prophet Muhammad (PBUH) used patience and tolerance, and acted in a manner that animosity changed to friendship and alliance. Of many such instances, the following is an example worth citing:

A Jewish woman, it is said used to throw dirt and sweepings on the Prophet from the roof of her room, when he would pass by her house. Then this suddenly stopped.

On the second day, the Holy Prophet (PBUH), mentioned this at the mosque and asked, "What has happened to her?" "She is sick," someone replied.

The Prophet went to her house and enquired about her health. This came as a great surprise to the woman, who was so impressed by his patience and tolerance, that she converted to Islam. 


\section{Questions:}

- Why did the Prophet release the captives from the Hawazen tribe?

- What impact did this have on the tribe?

- Why did the Prophet remain patient against the misdeeds of the Jewish woman?

- What was the result? 


\section{Think}

(Classroom atmosphere, students are sitting. A teacher enters the class)

Monitor of the Class: Stand up!

Teacher: Please sit down. Well, what day is it, today?

Students: Thursday.

Teacher: Today is the last day of the week. Let us talk of morality and do no book reading. What do you say to that?

Ahmad: Sir, I think it would be better if we finish the book.

Students: An informal discussion, in which all of us can participate freely, sir, would be better.

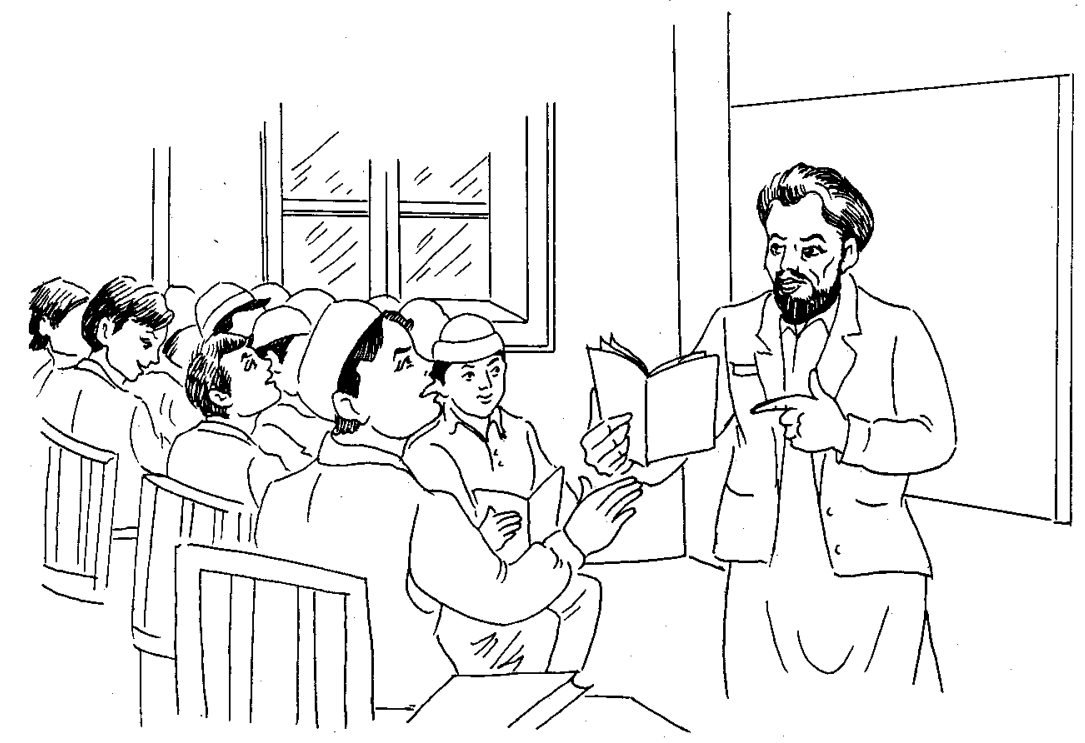

Teacher: All the students prefer a discussion, Ahmed. What is your opinion?

Ahmad: Sir, we will do what you decide upon.

Teacher: All right, a discussion then. If you agree I will begin the discussion with what Ahmad said today. What were his words?

Muhammad: Sir! he said, "We should read the book".

Teacher: No, I want Ahmad's complete answer. Can anyone repeat what he has said?

(Students whisper in each other's ears) 
Teacher: O.K. if you don't remember, let me tell you. He had said, "I think it would be better if we finish the book". I would like to discuss the words, "I think." What have you to say to that?

Muhammad: I did not follow you sir. What difference would it make whether we say, "I think", or not.

Teacher: It makes a lot of difference. We should express our opinion only. The others need not agree with us. "I think" indicates a personal view concerning a given matter, for the others are free to hold any opinion they like.

Maqsud: Sir, this is the custom of the English; the infidels speak like that.

Teacher: No, my dear. It is not the manner of speech of the English or infidels, it is our mode of expression, as well as that of our sages. If we attribute all our good practices and social graces to the English, not much good would be left to us. That would be an unkind joke on the Afghans and the Muslims.

Muhammad: Sir, is there anything in Islam concerning this matter?

Teacher: Islam does not specifically say that if one wishes to express one's opinion, one must necessarily say, I think. But there are several Quranic verses and traditions attributed to the Holy Prophet Muhammed (PBUH), which imply that one should not impose one's opinions on others, and whatever is said should be logically convincing. There is then, a likelihood of one's point of view being accepted.

Muhammad: Sir, give us an example.

Teacher: There is a verse in the Holy Quran which advises the Muslims, not to curse other people's gods, false though they are, for they might in retaliation revile "your God". This shows that one's beliefs whatever they be, are dear to one's heart. One should not, therefore, hurt other people's feelings, by showing lack of respect for their beliefs, or places of worship.

Maqsud: (Taking down notes in his notebook)

If there are other such things in the Holy Quran, please throw light on them as well, so that we can jot down the salient points.

Teacher: God says that, being Muslims, we should not force other people to renounce their faiths and become Muslims. In other words, we should not impose our belief on others.

Muhammad: Some more information, sir.

Teacher: The Holy Quran touches on all aspects of man's life, and provides solutions to problems he is likely to face, on this earth. For example, God asked the Prophet to "call people to your God with clear reasons and proofs, by way of advice and pleasant words." 
Thus the Almighty had instructed even His Prophet, to adopt an amiable and pleasing manner and way of address, in inviting the people to embrace Islam. As such being Muslims, we should follow the teachings of God and the example of our Prophet (PBUH). Moreover, one of God's names is Halim.

Ahmad: What does that mean?

Teacher: Halim is derived from the Arabic word "Hilm" which means mild tempered, gentle, tolerant and patient, while Halim means the most tolerant of all. God thus dislikes and disapproves of cruelty and oppression, and instructs all human beings to do likewise.

Karim: (Jokingly) Cheer up boy! the teacher has used your words to explain things to us.

Teacher: (Smiling) Well I used Ahmad's words because they seemed interesting to me. I will use words spoken by the other boys too, to serve as examples, if what they say also attracts our attention.

(Ahmad smiles and looks at the boys in the back rows)

Teacher: One important matter remains. Learn to imbibe the virtue of patience, and learn to respect other people's opinions. calmly.

Karim: What if a person beats me sir? I do not think I can put up with that

Teacher: Well what I am trying to stress is that if you respect other people's feelings, and do not initiate an argument or get violent, the likelihood is that there will neither be frayed tempers, nor the need for coming to blows. Respect, you may say, is mutual and not a one-sided affair. But each of us has had enough of the endless fighting going on, and that requires a change of heart and outlook in each one of us (the Afghans). We should learn a lesson from the on going strife and conflict, that has virtually devastated our country. Let us respect each other's opinions and learn to be tolerant.

Teacher: (Looking at his watch) Well, the class time is almost up.

Monitor: What should we do to cope with the situation then, sir?

Mahmood: The teacher has already explained that we should not behave impulsively, but think over matters coolly, and develop the habit of being tolerant and patient.

Maqsud: I agree.

Karim: I think besides what has been said, we should not give ourselves superior airs. This gives rise to doubts, suspicions, and eventually leads to misunderstandings and rifts.

(Every body talks, there is therefore, some noise) 
Teacher: (Raising his hand) Silence! I say silence. I am sure today's discussion has helped you to analyze and appreciate, some of the issues facing the people and the country. But before we leave, remember to make use of "I think," when expressing your opinion (The bell rings. The class leaves). 


\section{How Peace Disappeared from our Village}

Saboor Khan, a teacher by profession, all sweaty and seemingly worried and upset, wiped his face with a handkerchief, and asked for a glass of water on reaching a group of people in the village.

"I'll fetch you one instantly, and also something to eat," said Farid Kaka, Jan Mohammed's son, sitting at some distance from the others, and left to do so.

Taking his seat among the group Saboor, who hailed from a nearby village, and seemed known to the company, took off his shoes and in the process revealed his bloody shank.

Kaka Jan Mohammed, an elder of the village, addressed him thus: "My dear you show signs of distress. We hear of frequent brawling and suffering in your village. The 'Karazes'* are destroyed and the forests burnt. Only the other day I was told that some people had set fire to Lala Ghulam Hussain's harvest. Evil spirits seem to have taken possession of your village. Surely the goings on there have upset us. People of our two villages have lived like brothers for ages, and have faced good and bad times together. Now we cannot interact, because of security reasons. Tell me what has befallen you people."

Saboor, who expected this sort of questioning, cleared his throat and replied, "Dear uncle may God save us all from discord and strife. So long as we were united, everything went well, but with the elders falling apart, we have lost our bearings, resulting in much fighting and quarrelling."

"Please give us details of what has overtaken you, Headmaster," said Kaka Jan Mohammed. Saboor, reflected for a while, and explained: "For years we had lived as a well knit community in the village. We were like one family, with the younger set showing respect to the elders. We constructed a secondary school for girls on a self-help basis, made arrangements for the supply of potable water through contributions, and even managed to link our roads with other villages. But then there was good understanding among us at that time."

Interrupting him, Gul Mohammed said, "We know all this. We had always looked with envy, at the amity and friendly relations, existing among you, but how did you come to this sorry end?"

Saboor explained: Khyal Mohammed, Haji Jumma's son came to their village last autumn with some strangers, who disappeared the next morning. Some time later, another such group visited them and such visits were repeated. Now Khayal Mohammed did not say his prayers at the mosque. One day Saifuddin announced there that he had acquired weapons, for taking control of the village by force, adding that he would start off by taking repossession of the land, his father had lost.

\footnotetext{
* Karazes - man-made underground water channels for irrigation
} 
This shocked the audience, because the village had been threatened. Then someone shouted, "I have a suggestion! Before Saifuddin uses his weapons against us, let us be armed". These words virtually divided the people into two groups, and peaceful existence ever since, has become a distant dream. The girls' school was closed down followed by the closure of boys' school, and the hospital. Suspicions increased, as each took the other to be the enemy. As no one felt safe, people began to leave the village.

"A gun fire was heard yesterday," he said, "which was followed by screams and cries. A fire then engulfed the houses and the robbers looted the people. I was injured in the ensuing melee. No one's life seems safe."

Kaka Gul Mohammed, who had earlier moved to this village with his family and belongings, said with tearful eyes, "This is sheer barbarism! We enjoyed a peaceful life. Now look what has become of us. The entire village is in ruins."

News of the Headmaster's arrival spread in the village. The villagers heard his story in the mosque. Someone admonished him, "You destroyed your houses and now you say it is our turn." The others whispered, "Oh it was because of the corruption among them that they have faced such a consequence. To avoid the same fate we should not join them". Some people, having resigned to fate, expressed their opinion: it is nothing, only an aftermath of the revolution, there will be peace in the end. 


\section{Conflicts Should be Settled}

Difference in opinion and outlook has been, since time immemorial, a part of human existence. As members of a family, community or workplace, we tend to disagree on certain issues, and agree on others.

Such differences, whatever the issues are, have diverse causes and origins. These may arise from personal account, religious beliefs, collective grievances, racial prejudices, political aspirations, or conflicting ideological outlooks.

Man, though a rational animal has the power to do both good and evil. The power of goodness manifests itself in wishing well to others, and being helpful and cooperative. Meanwhile, the powers of evil assume the form of cruelty, exploitation of the weak and poor, selfishness, greediness, love of power, tyranny and various other forms. Islam, which provides its followers, a complete code of life, enjoins on the Muslims not to encroach upon other people's rights, because human beings are equal in the eyes of God. These are the core points, which a Muslim should bear in mind.

It is indeed our religious tenets that help us to overcome our evil tendencies. Religious knowledge acquaints us with the object of our being here, and the need to equip ourselves spiritually for the life to come.

If we do not lose sight of this goal, we shall always bear the teachings of our religion before us: be modest and humble, and tolerant towards other fellow beings, and respect their opinions and viewpoints, irrespective of caste, colour or creed, which cause all kinds of conflicts and tensions.

Man, being a social animal, with an instinct for self-preservation, lives in the society of other human beings. If we respect each other's views, beliefs, modes of life, customs and follow a policy of non-interference, there is little likelihood of any friction arising, or ill will or conflicts taking place. On the contrary, if we assume an aggressive posture, others are likely to be offended, which might lead to disturbance of the peace. Respect for each other's beliefs and connections should, however, be mutually inclusive, to bear fruit.

Educated societies in particular are distinct from the others, because of their civilized behaviour and desire to solve all differences through negotiations, dialogue and consultation. They do not, without cogent proof, believe in hearsay, nor are they misled by propaganda and thus live in peace and harmony.

The uneducated, meanwhile, prefer to decide issues through force, resulting in bloodshed and human misery.

The best way to solve differences is, to act in accordance with the accepted humanitarian and religious principles, and norms.

Most importantly, the best means for ensuring harmony is to educate the masses, because education helps a person to be civilized, tolerant and forbearing. Nevertheless, we should attempt to solve differences by making use of our 
reasoning power, to guide us. Let us not ignore what our religion has to say on such matters, only then can we, our families and the people at large, live in peace. 


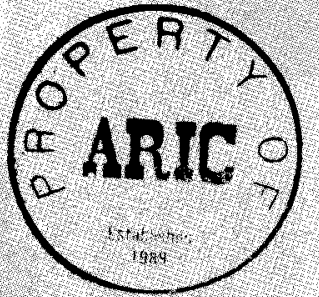

United Nations Educational Salentific and Cultural Organization

First Floor, Saudi Pak Tower P. O. Box 2034, Islamabad, Pakistan Tel $(92-51) 829452-829453-813308 \mathrm{Fax} \cdot(92.51) 825341$

E-mail.unesco@isb.compol.com 